\title{
THE PREMEIOTIC DNA REPLICATION OF EUCHROMATIN AND HETEROCHROMATIN IN LILIUM LONGIFLORUM (THUNB.)
}

\author{
by \\ PREBEN BACH HOLM \\ Department of Physiology, Carlsberg Laboratory, \\ Gamle Carlsberg Vej 10, DK-2500 Copenhagen, Valby
}

Key words: Premeiotic DNA replication, heterochromatin, autoradiography

The presynaptic stages of Lilium longiflorum have been analyzed in the light microscope. Seven substages can be defined on the basis of changes in morphology of the heterochromatin and the nucleoli. The duration of the presynaptic interval and the substages has been calculated from bud length measurements and cell stage gradients in the anthers. The premeiotic and somatic DNA replication has been investigated using ${ }^{3} \mathrm{H}$-thymidine autoradiography. The premeiotic $S$ phase lasts 50 hours whereas the somatic $S$ phase in root tip nuclei is six times shorter. Moreover, premeiotic $S$ phase nuclei house 2-3 times more heterochromatin than somatic nuclei. The premeiotic DNA replication can be divided into three periods: In early $S$ phase the DNA of euchromatin is replicated; in mid $S$ phase synthesis is arrested for a minimum of 9 hours; and in late $S$ phase the DNA of heterochromatin is replicated. DNA synthesis in heterochromatin is correlated with a dispersal of these chromatin regions. Determinations of volume and staining characteristics of heterochromatin after the application of $\mathrm{C}$ and $\mathrm{Q}$ banding procedures indicate that the premeiotic heterochromatin comprises $\mathrm{C}$ bands, $\mathrm{Q}$ bands and interbands. The premeiotic DNA replication is discussed in relation to the observed chromatin dynamics, and a proposal is made for the significance of the replication sequence to the formation of the leptotene chromosome and the control of crossing-over.

\section{INTRODUCTION}

The premeiotic interphase is generally not regarded as an integral part of eukaryote meiosis. Present evidence assigns the crossing - over proces to pachytene $(24,64,77)$, and three-dimensional reconstructions of leptotene and zygotene nuclei have proven the absence of pre-alignment of homologous chromosomes $(27,57)$. Several lines of evidence have, however, demonstrated the importance of the presynaptic interval in the control of the meiotic processes of chromosome pairing, fourstrand crossing - over and regular disjunction of the homologous chromosomes during the first meiotic division. The application of radiation, heat shocks and metabolic inhibitors to premeiotic nuclei have a severe impact on chromosome pairing and crossing-over at the later stages $(24,64)$, indicating that meiosis specific differentiation steps are occurring. 
Current hypotheses on the significance of the premeiotic interphase to meiosis are to a large extent based on results obtained with Lilium longiflorum. Culture experiments of extruded microsporocytes have demonstrated that the cells become irreversibly committed to meiosis during the premeiotic interphase $(54,63)$. The premeiotic DNA replication has been reported to be longer than somatic DNA replication ( 55 , 64) a characteristic found in all organisms in vestigated $(3,17,19,50)$ and in particular in the newt Triturus $(11,12,13)$. The major phase of premeiotic DNA replication terminates at the onset of leptotene $(29,32,71)$ but biochemical analyses have demonstrated that $0.3 \%$ of the DNA in Lilium is delayed in replication until zygotene $(29,32)$. This DNA fraction has been suggested to be of significance for chromosome pairing $(29,32,59)$. Histone synthesis has been reported to be uncoupled from DNA replication at this stage $(8,66)$, and a histone unique to meiosis with properties similar to the $\mathrm{H} 1$ histone is synthesized (60). The chromatin has been reported to undergo compaction before the leptotene stage $(5,6,74,75)$ similar to the situation in other organisms $(10,25)$. During the presynaptic interval in Lilium a succession of stages is identifiable by distinctive changes in the organization of the heterochromatin and the nucleoli, and it has been suggested that the premeiotic heterochromatin might have an impact on the control of the crossing-over process (65).

The present paper analyses the DNA synthesis during the presynaptic interval of Lilium longiflorum by autoradiography with special emphasis on the spatial separation of the replication of the DNA in euchromatin and that in heterochromatin. The synthesis pattern is compared to the pattern observed for somatic interphase. The morphology and organization of the heterochromatin at premeiotic interphase is studied with the aid of staining techniques used to characterize the bands of metaphase chromosomes.

\section{MATERIALS AND METHODS}

\subsection{Plant material.}

Buds and root tips were obtained from a clone of Lilium longiflorum grown in the phytotron of the Royal College of Forestry in Stockholm. The plants were cultivated under a 16 hours light period at $20^{\circ} \mathrm{C}$ followed by 8 hours in darkness at $15^{\circ} \mathrm{C}$. After flowering and withering the bulbs were transferred to a $5^{\circ} \mathrm{C}$ room for approximately 6 weeks. After this vernalization treatment a new flowering period could be induced. In addition some root tips were obtained from the same clone grown in a greenhouse in the Botanical Garden of Copenhagen. No differences were observed between these two materials.

\subsection{Bud length measurements}

For growth rate calculations bud length was measured by means of a slide-gauge to the nearest $0.1 \mathrm{~mm}$ at 24 hours intervals. In parallel approximately 100 buds were isolated, measured and the anthers fixed for autoradiographical, cytochemical or electron microspical investigations. These experiments were designed in order to establish a correlation between the presynaptic stages and bud length similar to the ones available for later meiotic stages (20). As described in section 3.1 these experiments failed because of difficulties in measuring with sufficient precision the length of the buds containing interphase and leptotene stages. A more time consuming procedure was therefore adopted in the experiments presented below.

\subsection{Labelling procedure for autoradiography}

Length of the buds was estimated without disturbing the inflorescence and the buds removed individually at appropriate stages of development. After measuring bud length the perianth was quickly removed and the exposed six anthers measured separately on mm paper. Using a grease free scalpel blade, each anther was slit longitudinally through the connective and immediately transferred to cotton stoppered glass tubes containing approximately $2 \mathrm{ml}$ incubation medium and covered with alufoil. The medium on which the anther halves float was the same as the one used for culturing 
meiocytes in vitro by ITo and STERN (38), consisting of WHITE's modified solution $+0.3 \mathrm{M}$ sucrose with $\mathrm{pH}$ adjusted to 5.6. Tubes and content were autoclaved at a pressure of 2 atmospheres for 20 minutes at $120^{\circ} \mathrm{C}$.

Immediately before use, thymidine $-6-{ }^{3} \mathrm{H}$ (Amersham, spec.act. $23 \mathrm{Ci} / \mathrm{mm}$ ) or thymine-6${ }^{3} \mathrm{H}$ (Amersham, spec. act. $21 \mathrm{Ci} / \mathrm{mm}$ ) were added to the culture medium to a final concentration of $50 \mu \mathrm{Ci} / \mathrm{ml}$.

Generally one of the six synchronous anthers was labelled with one of the tracers, whilst another was fixed immediately for cytochemistry. The remaining four were labelled with the other tracer, one of these being selected for DNase treatment. Anther halves were floated on the radioactive solution for two hours at $20^{\circ} \mathrm{C}$, washed several times in "cold" medium, briefly blotted dry on filter paper and transferred to glass vials for fixation. One half was fixed in 3:1 (absolute ethanol: glacial acetic acid) for two hours, washed for one hour in three successive changes of $70 \%$ ethanol and stored in $70 \%$ ethanol in a refrigerator. The other half was fixed for one hour in $4 \%$ formaldehyde in $0.05 \mathrm{M}-\mathrm{K}$ -

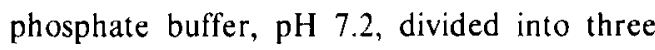
parts (tip, middle and base), and fixed for two more hours. Postfixation was carried out for two hours at room temperature in $2 \% \mathrm{OsO}_{4}$ in phosphate buffer. The material was subsequently washed twice in buffer and distilled water, dehydrated through a graded water-ethanol series and after one hour immersion in propylene oxide, embedded in SPURR's low viscosity epoxy resin (62). The formaldehyde was prepared as a $40 \%$ stock solution by alkaline hydrolysis of paraformaldehyde at $70^{\circ} \mathrm{C}$ and adjusted to $\mathrm{pH} 7.0$.

Root tips were labelled in the following manner: actively growing root tips were excised, washed in distilled water and incubated for 30 minutes at $20^{\circ} \mathrm{C}$ in darkness. The incubation medium contained $5 \mu \mathrm{Ci} / \mathrm{ml}$ thymidine- $6-{ }^{3} \mathrm{H}$ in distilled water, the same batch of thymidine being used for labelling both anthers and root tips. Fixation was carried out as described for anthers.

The method of QUASTLER and SHERMAN (56) was used for estimating the duration of the somatic $S$ phases in root tips. Excised and washed root tips were pulse-labelled for 30 minutes as described above and chased at $20^{\circ} \mathrm{C}$ in darkness for up to 36 hours in a solution of $10 \mu \mathrm{M} / \mathrm{ml}$ non-radioactive thymidine in distilled water. Samples were taken for fixation every second hour after a previous treatment with $0.05 \%$ colchicine for two hours. Fixation was carried out as described for anthers.

\subsection{Stage determination}

All material embedded in SPURR's resin was sectioned for stage determination, 10 sections approximately $1.5 \mu \mathrm{m}$ in thickness were cut from each block on a Huxley ultramicrotome using a dry glass knife. Sections of this thickness contain a reasonable amount of chromatin structure, and individual sections can easily be picked up from the knife edge with a pair of forceps. The material was transferred to water droplets on a precleaned slide and dried on a hot plate; after mounting in "Eukitt" the sections were analysed for meiotic stages using phase contrast optics.

\subsection{Squashing}

The desired stages of anther halves fixed in ethanol acetic acid were identified from the resin embedded sections. The anther halves were allowed to reach room temperature and subsequently hydrolyzed for 6 minutes in $1 \mathrm{~N}$ $\mathrm{HCl}$ at $60^{\circ} \mathrm{C}$. Each anther half was transferred to a drop of $45 \%$ acetic acid on a slide, divided into tip, middle and base and slit through the connective. In this way two identical series could be obtained, each containing one locule from tip, middle and base. Each part was squashed in $45 \%$ acetic acid on a slide and frozen in a squash slide freezer, the coverslip was flipped off and the slide washed twice in absolute ethanol. After three washes in $70 \%$ ethanol the squash preparations were stored overnight in a refrigerator. Next day the ethanol was poured off and the slides were allowed to dry in air at room temperature.

\subsection{DNase digestion}

Air - dried slides from the ethanol acetic acid fixed anthers were transferred to $0.05 \mathrm{M}-\mathrm{K}$ phosphate buffer containing $0.003 \mathrm{~mol} / \mathrm{l}$ 
$\mathrm{MgSO}_{4}, \mathrm{pH} 6.5$ for five minutes, blotted free of surplus buffer and incubated for four hours at room temperature with $0.1 \%$ DNase (DNase I, Worthington, Code DPFF, RNase free) in phosphate buffer. The slides were subsequently washed in buffer, transferred to $5 \%$ TCA for 15 minutes at $0-4^{\circ} \mathrm{C}$, washed 15 minutes in cold running tap water, dipped in distilled water and dehydrated to $70 \%$ ethanol. The preparations were either air-dried the same day or stored refrigerated overnight. Control slides were treated identically, omitting DNase in the incubation step.

Formaldehyde fixed material was treated as follows: After three hours fixation in $4 \%$ formaldehyde followed by several washes in buffer, the anther parts were sliced into thin segments and stored refrigerated over night in $0.05 \mathrm{M}-\mathrm{K}$-phosphate buffer, containing 0.003 $\mathrm{mol} / \mathrm{MgSO}_{4}$. The material was then digested for seventeen hours at $20^{\circ} \mathrm{C}$ in $0.1 \%$ DNase in phosphate buffer, rinsed for 15 minutes in $5 \%$ TCA at $0-4^{\circ} \mathrm{C}$ and finally washed in buffer and distilled water. Subsequent processing was identical to that described in section 2.3 for embedding in epoxy resin. Controls were carried out by omitting the DNase in the incubation step.

\subsection{Autoradiographical procedure}

Ilford L4 liquid emulsion was melted at $43^{\circ} \mathrm{C}$ in a waterbath, diluted with two volumes of preheated water, gently stirred to homogeneity and transferred to a waterbath at $20^{\circ} \mathrm{C}$ for 30 minutes. The emulsion was then ready; more water was added if necessary to ensure proper emulsion thickness (see below). Air dried slides of squashes and slides with attached resin sections were dipped in the emulsion and placed horizontally on trays for drying over silica gel. This procedure gives a reproducible emulsion layer with a blue to green interference colour indicating an emulsion thickness about twice that of a monolayer. Previous experiments with purple monolayers gave unduly inconsistent results, especially with squash preparations.

When dry, the slides were transferred to black slide boxes with silica gel and exposed for up to three months at $3-5^{\circ} \mathrm{C}$. The emulsion was developed for three minutes at $20^{\circ} \mathrm{C}$ in full strength Microdol $\mathrm{X}$, transferred to $1 \%$ acetic acid for 30 seconds and fixed in $20 \%$ sodium thiosuiphate $+2.5 \%$ potassium metabisulphite for 5-7 minutes. After 15 minutes washing in running distilled water the squash preparations were stained for 15 minutes in $0.05 \%$ Azur B in Mcllvaine buffer $\mathrm{pH} 4.0$, washed in distilled water, air dried and mounted in "Eukitt". Other autoradiographs have been stained with Feulgen before the processing for autoradiography and no differences between the Feulgen and the Azur B staining patterns have been observed. After $\mathrm{HCl}$ hydrolysis only chromatin structures are stained, and no staining can be observed after DNase treatment. This poststaining method seems to have some advantages over traditional Feulgen staining: no interaction between stain and emulsion can occur during long exposures, and the very faint staining of the emulsions provides a control of emulsion evenness and thickness. The slides with resin sections were viewed in phase contrast.

Silver grains were counted directly from the autoradiographs at a magnification of $\times 1600$. Grain counts were specified for three chromatin fractions: euchromatin, heterochromatin and the junction between the euand heterochromatin. The junction will be referred to as hetero-euchromatin border. Nuclear and cytoplasmic activity was counted from a randomly selected area and background from adjacent areas, which in phase contrast proved to be free of cellular debris.

A total of 20 buds ranging in development from early archesporial stages to mid zygotene has been pulse-labelled and analyzed by autoradiography. Other labelling procedures have been tried with less success. Stripped buds i.e. buds where the perianth has been removed (31) were floated on the incubation medium for twenty hours and the anthers fixed in the usual way. Alternatively, anthers have been isolated one at a time from partially opened buds over a period of three days and pulse-labelled.

\subsection{Area and volume calculations}

Nuclei were selected at random from the autoradiographs of squashed preparations and 
photographed on $35 \mathrm{~mm}$ Agfa Ortho 25 in a Zeiss photomicroscope. Prints were made at a magnification of $\times 3000$. The outline of the nucleus, defining nuclear area, and the outline of the heterochromatin, defining heterochromatin area, were drawn on semitransparent graph paper and the areas were calculated. The area of euchromatin and borders between eu- and heterochromatin were calculated by subtracting the heterochromatin area from the nuclear area. For volume determinations each chromocenter was assumed to be spherical, and the volume of the individual chromocenters could accordingly be calculated from the area measurement.

\subsection{Feulgen, Giemsa $C$ and Quinacrine mustard staining}

Giemsa $\mathrm{C}$ staining was performed according to I. Summer (69), II. Vosa and MARCHI (73) and III. as follows (26): Air-dried squash preparations were treated with $0.01 \mathrm{M}-\mathrm{Ba}(\mathrm{OH})_{2}$ for five minutes followed by incubation for 4-6 hours in $2 \times \mathrm{SSC}$ at $60^{\circ} \mathrm{C}$, and subsequently stained in Giemsa (R66,GURR) diluted 50 fold with 1/15 M-phosphate buffer $\mathrm{pH} 7.0$.

Quinacrine mustard staining was performed as described by CASPERSSON et al. (14). After initial analysis and photographing of the fluorescence patterns in interphase nuclei, acetic orcein was added and the slides made permanent. Previously photographed nuclei were identified and rephotographed and the negatives contact copied. Prints from the quinacrine mustard and orcein stained nuclei were now directly comparable and area calculations were carried out as described in section 2.8 .

Due to the fluorescence image, the quinacrine mustard stained chromocenters were slightly larger than those stained with orcein. In Table IX the size of the quinacrine mustard stained area of the chromocenters was therefore reduced to correspond to the orcein value.

\section{RESULTS}

\subsection{Growth rates of buds}

The presynaptic stages have been found in buds ranging in size from $10-15 \mathrm{~mm}$. Buds of this length are not easily available for measurements since they are partially covered by leaves and other buds in the inflorescence. Measurement in situ therefore always introduces some damage to the buds and has been found to result in a reduced growth rate.

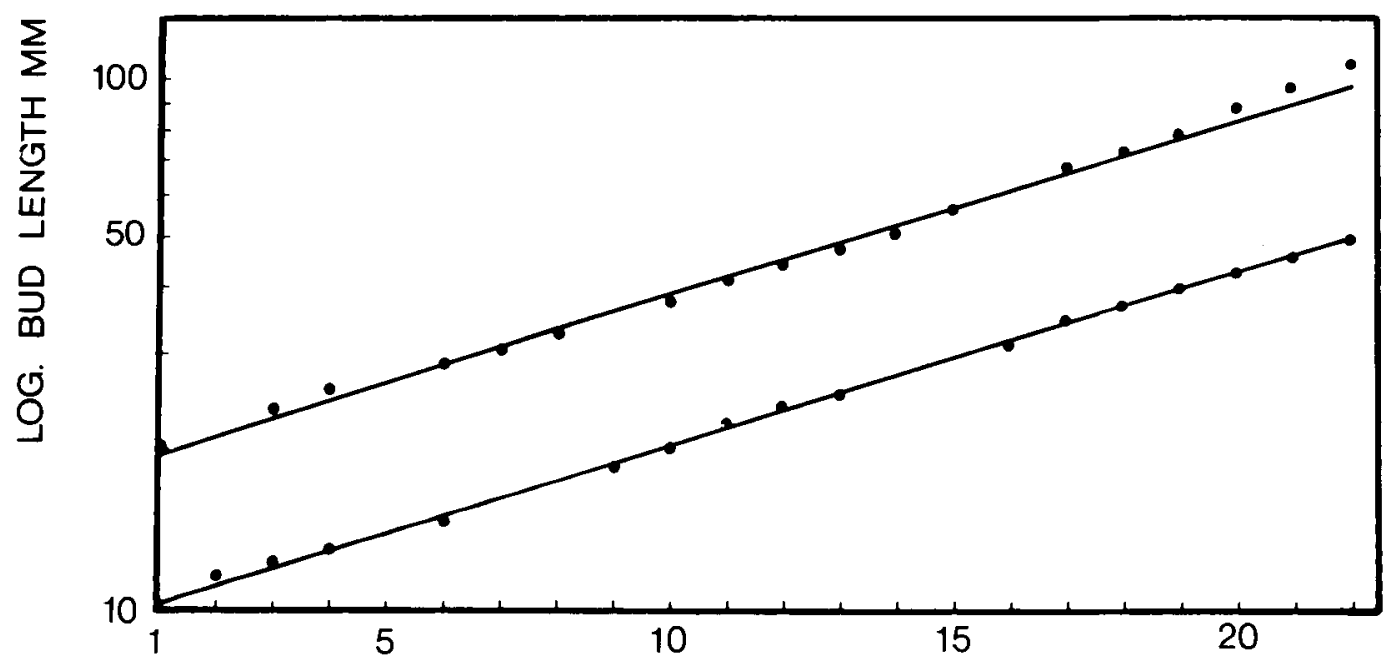

Figure 1. Growth rates for two buds of Lilium longiflorum 


\section{P. B. HoLm: Premeiotic DNA replication in Lilium}
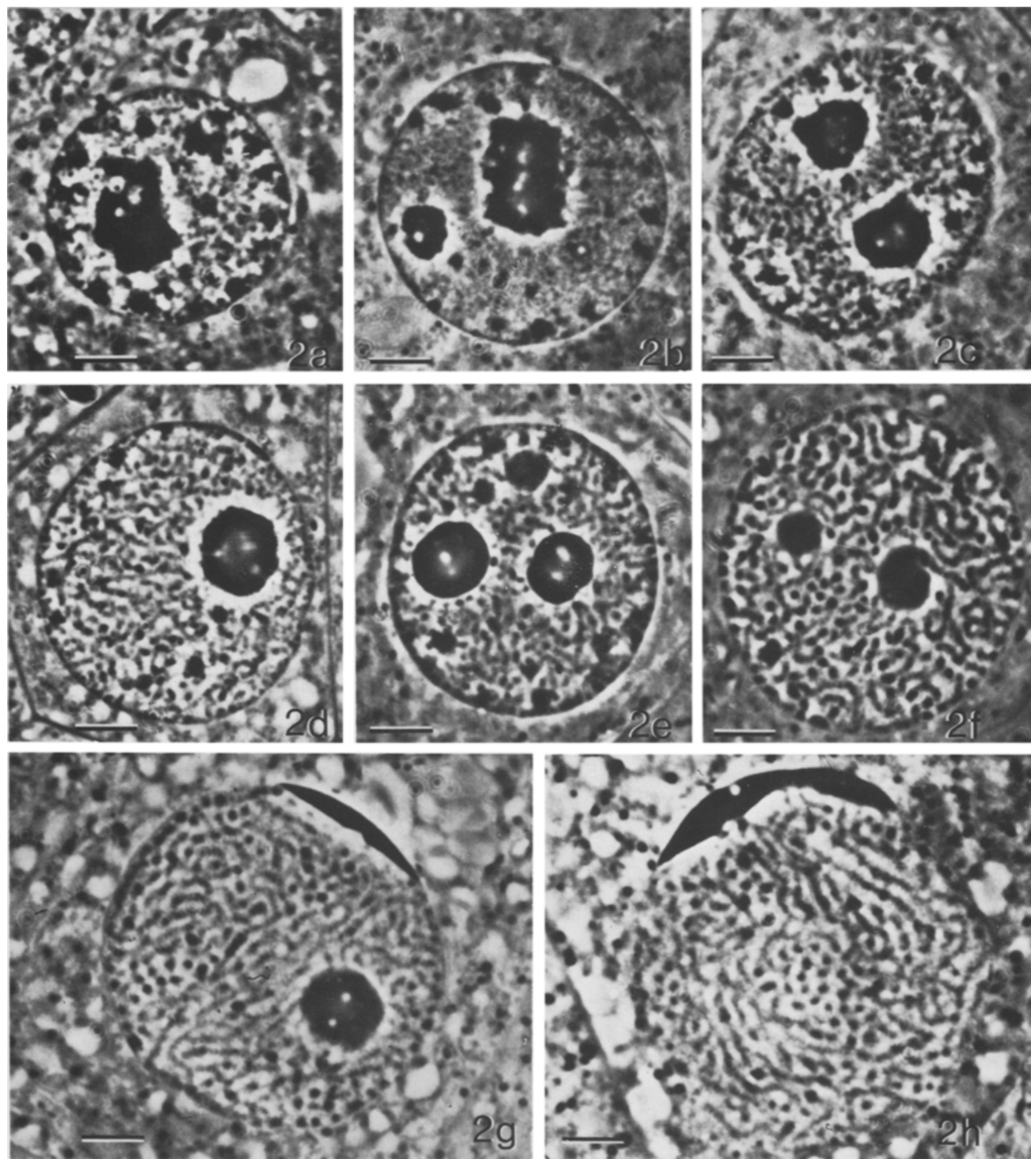

Figure 2. The substages of the premeiotic interphase and leptotene in Lilum longiflorum.

Distinct changes in the morphology and distribution of the euchromatin, heterochromatin and the nucleoli can be observed. $2 \mathrm{a}, \mathrm{G}_{1} ; 2 \mathrm{~b}, \mathrm{~S}_{1} ; 2 \mathrm{c}, \mathrm{S}_{2} ; 2 \mathrm{~d}, \mathrm{~S}_{3} ; 2 \mathrm{e}$, early leptotene; $2 \mathrm{f}$, early-mid leptotene; $2 \mathrm{~g}$, mid leptotene; $2 \mathrm{~h}$, late

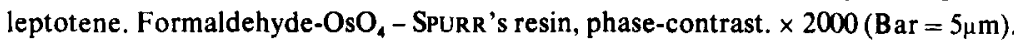


Furthermore measurements are difficult to perform with sufficient precision in a cluster of buds. For these reasons another method had to be used and in combination with the autoradiographical experiments all buds except one were removed from the inflorescence and the remaining bud followed until anthesis. This procedure gives a good logarithmic correlation between bud size and time, demonstrating that buds under controlled conditions have a constant growth rate during the pre- and postsynaptic stages (Figure 1). By insertion of bud length and time into the exponential equation describing the growth curve, a value of $7 \%$ growth pr. 24 hours has been obtained. This growth rate is identical to the ones found in other studies on the growth of Lilium longiflorum buds $(6,20,71)$.

\subsection{Light microscopic morphology of presynaptic stages}

A morphological description of the presynaptic stages in Lilium has been given by STERN, WestergaARD \& vON WeTtSTEIN (65). The autoradiographical data necessitate a minor extension of the terminology.

Meiocytes in Lilium longiflorum generally enter the premeiotic Sphase when the buds are 10-11 mm long. The cells undergo a synchronization during $G_{1}$. Eighteen hours before DNA replication is initiated virtually no mitotic divisions can be found. Since the archesporial divisions are asynchronous, the $G_{1}$ period between the last mitosis and the premeiotic $S$ phase must vary from cell to cell and can exceed eighteen hours, but no quantitative data are available on the in vivo schedule of this premeiotic synchronization.

The sequence of morphological changes in presynaptic nuclei beginning in $G_{1}$ and extending into leptotene is illustrated in Figure 2. The most prominent changes occur in the heterochromatin or chromocenters and in the nucleoli. During $G_{1}$ the heterochromatin is preferentially located close to the nuclear envelope (Figure $2 a$ ). The nucleoli are irregular in outline and associated with heterochromatin. Many of the chromocenters stain heterogenously and appear to consist of regions with high and low density. This heterogeneity is equally evident after Feulgen, Azur B or orcein staining, as well as in unstained sections viewed in phase contrast.

The transition between $G_{1}$ and the first stage of DNA replication, termed $S_{1}$, is accompanied by a large increase in nuclear volume. The chromocenters become more diffuse in outline and may sometimes appear hollow. The nucleoli are unaltered in morphology, and the euchromatin is smoothly distributed in fine threads (Figures 2b, 4). In the following substage, the euchromatic chromatin becomes more conspicuous and can be seen as a reticulum of thicker threads (Figures 2c, 5, 13). This interval is designated as $\mathrm{S}_{2}$ at the end of which heterochromatin starts to replicate. In the stage termed $S_{3}$ the strands are well defined (Figures 2d, 6, 12a-b). The heterochromatin is variable in organization indicating that it undergoes reversible conformational changes. In some nuclei the chromocenters have loosened and are entirely replaced by balls of threads with a staining intensity comparable to those of the euchromatin. In the majority of the nuclei this dispersal of the heterochromatin is limited to minor parts of the nucleus. At this stage the nucleoli begin to transform from an irregular to a round shape.

When the nucleoli are rounded off, the meiocytes have entered the stage defined as early leptotene (Figures 2e, 12c-d). At this stage the heterochromatin has doubled in volume (see section 3.5) and beside the heterogenous larger chromocenters bipartite chromocenters can be recognized. Extreme condensation of the chromatin, as described for the late interphase-early leptotene stage in certain Lilium hybrids and varieties $(5,6,74,75)$ has never been observed in this clone. As the leptotene chromosomes thicken the heterochromatic lumps disappear successively (Figure 2f), and by mid leptotene very little heterochromatin remains. Some heterochromatic lumps can be recognized as local thickenings of leptotene chromosomes (Figures $2 \mathrm{~g}, 12 \mathrm{e}-\mathrm{f}$ ). Concomitantly the nucleoli begin to move towards the nuclear envelope and flatten into crescent shaped structures. This stage is defined as mid leptotene. In late leptotene the only remaining heterochromatin consists of nucleolus associ- 
ated knobs. All nucleoli are now flattened and many of them fused along the nuclear envelope (Figure 2h).

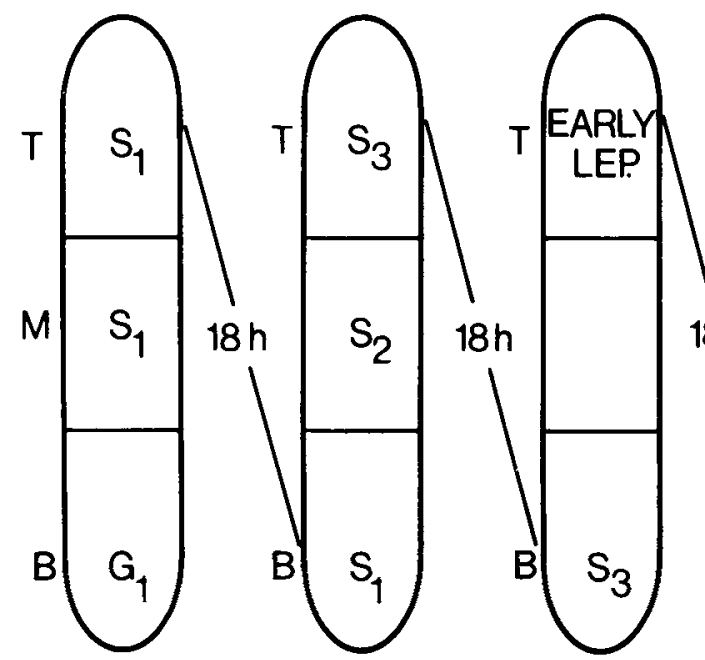

\subsection{Duration of the presynaptic stages}

In the present study the duration of the substages of interphase and leptotene had to be estimated indirectly, as experiments in which individual anthers were removed from partially

Figure 3. Temporal sequence of the presynaptic stages as elucidated by a continuous series of base-tip gradients in the anthers. The time difference of 18 hours between the gradients was calculated from the mean length of buds housing two adjacent anther gradients and the growth rate of $7 \% / 24$ hours, (see Table I).

T, tip; M, middle; B. base.

\section{Table I}

The time difference between the anther gradients.

The time difference was calculated from the mean bud length housing sequential anther types and the measured growth rate of $7 \% / 24$ hours.

SD, standard deviation.

\begin{tabular}{|c|c|c|c|c|c|c|c|}
\hline $\begin{array}{l}\text { anther } \\
\text { gradient }\end{array}$ & $\begin{array}{c}\text { tip } \\
\text { middle } \\
\text { base }\end{array}$ & $\begin{array}{l}S_{1} \\
\\
S_{1} \\
G_{1}\end{array}$ & $\begin{array}{l}\mathrm{S}_{3} \\
\mathrm{~S}_{2} \\
\mathrm{~S}_{1}\end{array}$ & $\begin{array}{c}\begin{array}{c}\text { early } \\
\text { leptotene }\end{array} \\
\mathrm{S}_{3} \\
\mathrm{~S}_{3}\end{array}$ & $\begin{array}{c}\text { mid } \\
\text { leptotene } \\
\text { early } \\
\text { leptotene } \\
\text { early } \\
\text { leptotene }\end{array}$ & $\begin{array}{c}\text { late } \\
\text { leptotene } \\
\text { mid } \\
\text { leptotene } \\
\text { mid } \\
\text { leptotene }\end{array}$ & $\begin{array}{c}\text { early } \\
\text { zygotene } \\
\text { late } \\
\text { leptotene } \\
\text { late } \\
\text { leptotene }\end{array}$ \\
\hline number of buds & & 10 & 8 & 3 & 3 & 5 & 6 \\
\hline mean bud length $\mathrm{mm}$ & & 10.9 & 11.6 & 12.1 & 12.8 & 13.5 & 14.2 \\
\hline SD & & 0.7 & 0.8 & 0.6 & 1.4 & 0.7 & 1.1 \\
\hline time difference hours & & \multicolumn{2}{|c|}{20} & \multicolumn{2}{|c|}{20} & \multicolumn{2}{|c|}{17} \\
\hline
\end{tabular}


opened buds at regular time intervals resulted in temporary arrest of the development of the anthers after the initial opening of the buds.

The tip, mid and base part of anthers from 35 buds were analyzed in detail by light microscopic observations of sectioned and squashed material. The existence of a basipetal developmental gradient within the anther as described in other studies of Lilium longiflorum $(5,71)$ has been confirmed. The sequence of stages within the anther has been found to be very consistent and only minor variation was noted among the six anthers of the bud. In most buds all anthers were in perfect synchrony as judged by morphological characteristics, but it was occasionally observed that one anther was slightly more advanced in development at the cellular level.

The presynaptic stages can accordingly be presented as a continuous series of developmental gradients (Figure 3). Moreover it is possible to calculate the time difference between these individual gradients using the mean lengths of buds housing two sequential types of gradients and the observed growth rate of $7 \% / 24$ hours. The results presented in Table I demonstrate that the established sequence of developmental gradients is valid, the individual gradients being separated in time by $16-20$ hours. Since the developmental difference between the anther gradients is $2 / 3$ of the base-tip difference, the mean time difference between the stages housed in the tip and the base of the anthers is 24-30 hours. The duration of the individual stages of the presynaptic interval can accordingly be calculated and it can be seen from Table II that the premeiotic Sphase and leptotene last for 40-50 hours and 48-60 hours respectively.

\subsection{The premeiotic DNA replication}

As described in section 3.2 the presynaptic interval can be subdivided by morphological characteristics into seven substages. The following autoradiographical data provide evidence that these substages can be correlated with events in the course of DNA replication.

An example of the autoradiographic data for an anther containing cells in $G_{1}$ at the base and in $S_{1}$ at the tip is presented in Figure 4 and
Table II

The duration of the presynaptic stages

The duration was calculated from the developmental difference of 27 hours between the stages in the base and the tip of an anther and the mean time difference of 18 hours between the sequential anther gradients.

\[ \mathrm{G}_{1}: \text { exceeds } 18 \text { hours } \]
$\mathrm{S}_{1}: 18$ hours
$\mathrm{S}_{2}: 9$ hours
$\mathrm{S}_{3}: 18$ hours
early leptotene $: 18$ hours
mid leptotene $: 18$ hours
late leptotene : 18 hours

Table III. The most advanced meiocytes localized in the tip of the anther are heavily labelled and have an $S_{1}$ morphology (Figure 4). In the middle of the anther, the activity is lower and in the base all meiocytes are very weakly labelled. The results of Table III can be summarized as follows: 1 . The majority $(75 \%)$ of the nuclear radioactivity is DNase digestible. 2. The labelling over heterochromatin is insignificant, two-thirds of the activity being confined to euchromatin and the remaining onethird to the border between eu- and heterochromatin. 3. Externally supplied thymidine is metabolized and the degradation products incorporated into a non-DNA fraction. The cytoplasmic radioactivity is variable and DNase resistant. 4. Meiocytes in the base of the anther are in the $\mathrm{G}_{1}$ stage.

An identical pattern has been observed in sectioned material (Table V). The labelling of cells in $S_{1}$ is again confined to euchromatin and the border region. $75 \%$ of the nuclear radioactivity is DNase digestible while the cytoplasmic labelling is DNase resistant and variable. The replication characteristics of the subsequent stages in premeiotic $\mathrm{S}$ phase are presented in Table IV. Nuclei in the base of the anther show the morphology and the labelling characteristic of the $S_{1}$ stage. In the 42 days exposure series approximately $80 \%$ of the nuclear radioactivity is DNase digestible. The mid parts of the anthers house meiocytes with $\mathrm{S}_{2}$ morphology (Figure 5). Nuclear labelling has decreased considerably, with only one of the six analyzed groups of cells showing appreciable 


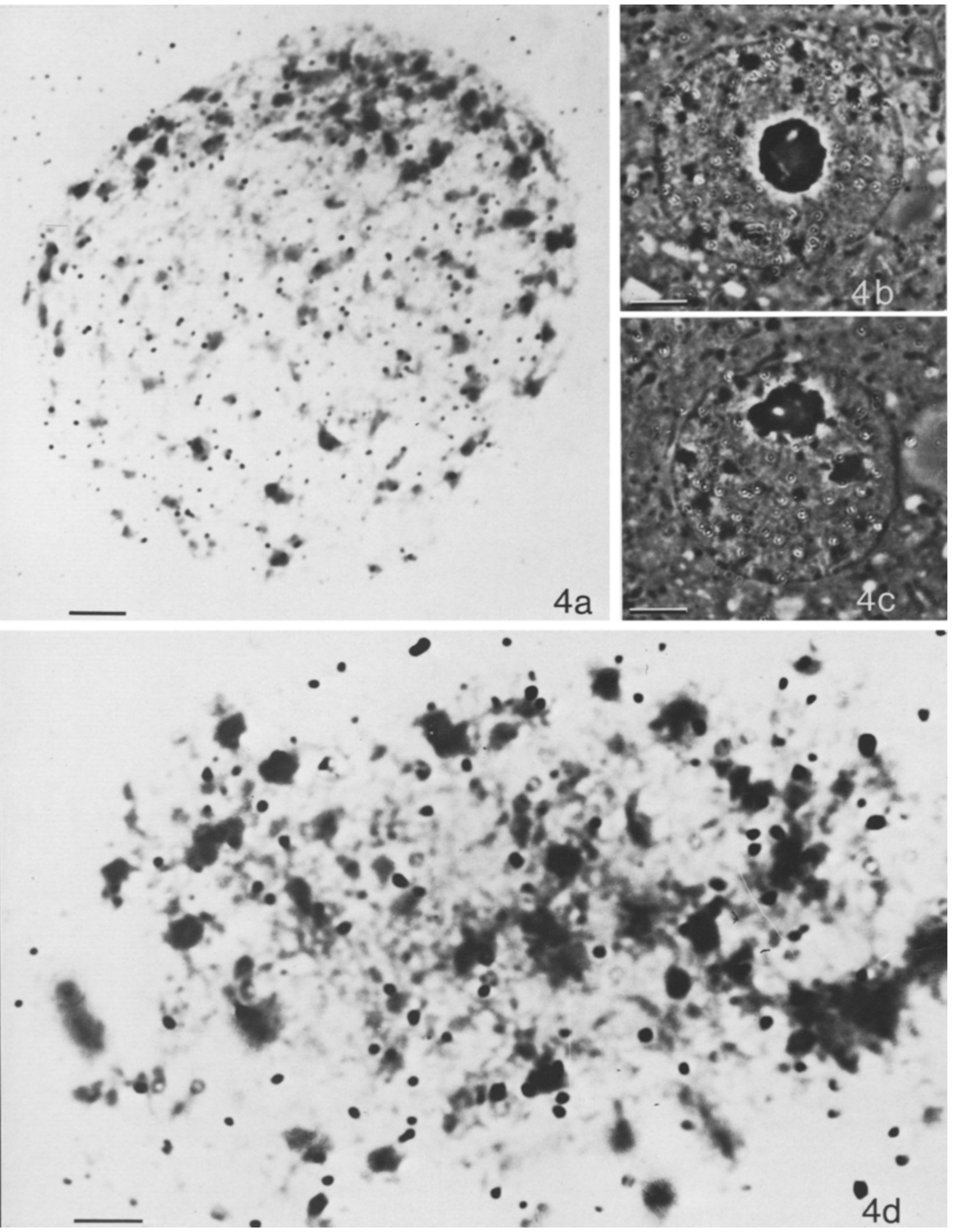


Figure 4. Labelling pattern in premeiotic $S_{1}$ nuclei.

The smoothly distributed euchromatin consists of fine fibrils and the majority of the silver grains are located above the euchromatin and the junctions between euchromatin and heterochromatin. Figure 4a. Survey micrograph of squashed nucleus in the $\mathrm{S}_{1}$ stage. $\times 2000(\mathrm{Bar}=5 \mu \mathrm{m})$. Figure $4 \mathrm{~b}$-c. Survey micrographs of sectioned nuclei. $\times 2000(\mathrm{Bar}=5 \mu \mathrm{m}) .4 \mathrm{~d}$. Detail of squashed $S_{1}$ nucleus. $\times 6000(\mathrm{Bar}=5 \mu \mathrm{m})$.

Table III

Incorporation of thymidine-6- ${ }^{3} \mathrm{H}$ into meiocytes at the premeiotic $S_{1}$ stage. Grain counts are given for squash preparations of anther halves labelled for two hours. The number of grains were counted over $900 \mu \mathrm{m}^{2}$ of nuclear area, $900 \mu \mathrm{m}^{2}$ of cytoplasmic area and $900 \mu \mathrm{m}^{2}$ of an area free of cell structures (background). Specific activity of the heterochromatin is obtained from the number of grains on heterochromatin per $1000 \mu \mathrm{m}^{2}$ nuclear area and the area covered by the heterochromatin in this portion of the nucleus. For the calculation of the specific activity of euchromatin and the border between eu- and heterochromatin the area is obtained by subtracting the heterochromatin area from $1000 \mu \mathrm{m}^{2}$. This area thus includes the karyoplasm. The background has been subtracted in both calculations.

a, squashes; $b$, squashes made as controls to DNase treatment ; $c$, squashes DNase treatment ; SE, standard error.

\begin{tabular}{|c|c|c|c|c|c|c|c|c|c|c|c|}
\hline \multirow[t]{2}{*}{$\begin{array}{l}\text { Anther } \\
\text { portion }\end{array}$} & \multirow[t]{2}{*}{ Stage } & \multirow[t]{2}{*}{$\begin{array}{l}\text { Proce- } \\
\text { dure }\end{array}$} & \multirow{2}{*}{$\begin{array}{l}\text { Expos- } \\
\text { ure } \\
\text { days }\end{array}$} & \multirow{2}{*}{$\begin{array}{l}\text { Meio- } \\
\text { cytes } \\
\text { counted }\end{array}$} & \multicolumn{5}{|c|}{$\begin{array}{l}\text { Grains per } 1000 \mu m^{2} \\
\text { minus background }\end{array}$} & \multicolumn{2}{|c|}{$\begin{array}{l}\text { DNase sensitive } \\
\text { grains per } 1000_{\mu} \mathrm{m}^{2}\end{array}$} \\
\hline & & & & & nucleus & $S E$ & \multicolumn{2}{|c|}{ cytoplasm } & SE & nucleus & cytoplasm \\
\hline tip & $S_{1}$ & $\begin{array}{l}a \\
b \\
c\end{array}$ & $\begin{array}{l}45 \\
45 \\
45\end{array}$ & $\begin{array}{l}27 \\
19 \\
26\end{array}$ & $\begin{array}{l}44.1 \\
47.6 \\
10.9\end{array}$ & $\begin{array}{l}6.7 \\
3.2 \\
1.0\end{array}$ & \multicolumn{2}{|c|}{$\begin{array}{l}15.5 \\
23.7 \\
16.5\end{array}$} & $\begin{array}{l}3.0 \\
2.1 \\
1.9\end{array}$ & $\begin{array}{l}33.2 \\
36.7\end{array}$ & $\begin{array}{l}0 \\
7.2\end{array}$ \\
\hline middle & $S_{1}$ & $\begin{array}{l}a \\
b \\
c\end{array}$ & $\begin{array}{l}45 \\
45 \\
45\end{array}$ & $\begin{array}{l}24 \\
27 \\
20\end{array}$ & $\begin{array}{r}13.8 \\
28.2 \\
8.1\end{array}$ & $\begin{array}{l}1.2 \\
2.2 \\
0.8\end{array}$ & \multicolumn{2}{|c|}{$\begin{array}{l}13.0 \\
17.6 \\
11.5\end{array}$} & $\begin{array}{l}1.4 \\
1.2 \\
1.0\end{array}$ & $\begin{array}{r}5.7 \\
20.1\end{array}$ & $\begin{array}{l}1.5 \\
6.1\end{array}$ \\
\hline base & $\mathrm{G}_{1}$ & a & 45 & 15 & 5.9 & 1.2 & \multicolumn{2}{|c|}{9.0} & 1.7 & & \\
\hline & & & & & \multicolumn{5}{|c|}{$\begin{array}{c}\text { Grains per } 1000 u \mathrm{~m}^{2} \\
\text { nuclear area }\end{array}$} & \multicolumn{2}{|c|}{$\begin{array}{c}\text { Specific activity } \\
\text { grains per } 1000 \mu \mathrm{m}^{2}\end{array}$} \\
\hline & & & & & $\begin{array}{c}\begin{array}{c}\text { hetero- } \\
\text { chromatin }\end{array} \\
\end{array}$ & \multicolumn{2}{|c|}{$\begin{array}{l}\text { euchro- } \\
\text { matin }\end{array}$} & \multicolumn{2}{|c|}{$\begin{array}{c}\text { hetero- } \\
\text { euchro- } \\
\text { matin } \\
\text { border }\end{array}$} & $\begin{array}{c}\text { hetero- } \\
\text { chromatin }\end{array}$ & \begin{tabular}{|l} 
euchro- \\
matin + \\
hetero- \\
euchro- \\
matin \\
border
\end{tabular} \\
\hline tip & $S_{1}$ & $\begin{array}{l}\mathrm{a} \\
\mathrm{b}\end{array}$ & $\begin{array}{l}45 \\
45\end{array}$ & $\begin{array}{l}27 \\
19\end{array}$ & $\begin{array}{l}1.3 \\
1.4\end{array}$ & \multicolumn{2}{|c|}{$\begin{array}{l}36.3 \\
35.1\end{array}$} & \multicolumn{2}{|c|}{$\begin{array}{l}18.9 \\
16.5\end{array}$} & $\begin{array}{l}6 \\
9\end{array}$ & $\begin{array}{l}47 \\
54\end{array}$ \\
\hline middle & $S_{1}$ & $\begin{array}{l}\mathrm{a} \\
\mathrm{b}\end{array}$ & $\begin{array}{l}45 \\
45\end{array}$ & $\begin{array}{l}24 \\
27\end{array}$ & $\begin{array}{l}0.1 \\
0.7\end{array}$ & \multicolumn{2}{|c|}{$\begin{array}{l}13.2 \\
19.5\end{array}$} & \multicolumn{2}{|c|}{$\begin{array}{r}5.4 \\
10.0\end{array}$} & $\begin{array}{l}0 \\
8\end{array}$ & $\begin{array}{l}15 \\
30\end{array}$ \\
\hline base & $G_{1}$ & a & 45 & 15 & 0 & \multicolumn{2}{|c|}{6.5} & \multicolumn{2}{|c|}{1.8} & 0 & 6 \\
\hline
\end{tabular}


Table IV

Incorporation of thymidine-6- ${ }^{3} \mathrm{H}$ into meiocytes at the premeiotic $S_{1}, S_{2}$ and $S_{3}$ stage. For experimental details see Table III. Procedures: a, squashes; $b$, DNase treatment.

\begin{tabular}{|c|c|c|c|c|c|c|c|c|c|c|}
\hline \multirow[t]{2}{*}{$\begin{array}{l}\text { Anther } \\
\text { portion }\end{array}$} & \multirow[t]{2}{*}{ Stage } & \multirow[t]{2}{*}{$\begin{array}{l}\text { Proce- } \\
\text { dure }\end{array}$} & \multirow{2}{*}{$\begin{array}{l}\text { Expo- } \\
\text { sure } \\
\text { days }\end{array}$} & \multirow{2}{*}{$\begin{array}{l}\text { Meio- } \\
\text { cytes } \\
\text { counted }\end{array}$} & \multicolumn{4}{|c|}{$\begin{array}{c}\text { Grains per } 1000 \mu \mathrm{m}^{2} \text { minus } \\
\text { background }\end{array}$} & \multicolumn{2}{|c|}{$\begin{array}{c}\text { DNase sensitive } \\
\text { grains per } 1000 \mu \mathrm{m}^{2}\end{array}$} \\
\hline & & & & & nucleus & $\mathrm{SE}$ & $\begin{array}{l}\text { cyto- } \\
\text { plasm }\end{array}$ & $\mathrm{SE}$ & nucleus & $\begin{array}{l}\text { cyto- } \\
\text { plasm }\end{array}$ \\
\hline tip & $\mathrm{S}_{3}$ & $\begin{array}{l}a \\
b \\
a \\
a \\
b\end{array}$ & $\begin{array}{l}42 \\
42 \\
70 \\
70 \\
70\end{array}$ & $\begin{array}{l}40 \\
40 \\
11 \\
20 \\
20\end{array}$ & $\begin{array}{r}12.7 \\
3.2 \\
44.3 \\
61.2 \\
18.0\end{array}$ & $\begin{array}{l}2.2 \\
0.6 \\
6.6 \\
3.1 \\
1.4\end{array}$ & $\begin{array}{r}3.2 \\
3.5 \\
7.4 \\
11.0 \\
15.5\end{array}$ & $\begin{array}{l}0.5 \\
0.6 \\
3.2 \\
1.4\end{array}$ & $\begin{array}{r}9.5 \\
26.3 \\
43.2\end{array}$ & $\begin{array}{l}0.6 \\
4.9 \\
0\end{array}$ \\
\hline middle & $S_{2}$ & $\begin{array}{l}\mathrm{a} \\
\mathrm{a} \\
\mathrm{b} \\
\mathrm{a} \\
\mathrm{a} \\
\mathrm{b}\end{array}$ & $\begin{array}{l}42 \\
42 \\
42 \\
70 \\
70 \\
70\end{array}$ & $\begin{array}{l}40 \\
40 \\
20 \\
40 \\
40 \\
20\end{array}$ & $\begin{array}{r}4.1 \\
0.1 \\
5.6 \\
13.5 \\
2.2 \\
1.7\end{array}$ & $\begin{array}{l}1.1 \\
0.3 \\
0.8 \\
2.1 \\
1.4 \\
1.0\end{array}$ & $\begin{array}{l}1.5 \\
0 \\
3.9 \\
5.7 \\
4.9 \\
1.3\end{array}$ & $\begin{array}{l}0.9 \\
\\
0.9 \\
1.5 \\
1.6 \\
1.4\end{array}$ & $\begin{array}{c}0 \\
0 \\
\\
11.8 \\
0.5\end{array}$ & $\begin{array}{l}0 \\
0 \\
\\
4.3 \\
3.6\end{array}$ \\
\hline base & $S_{1}$ & $\begin{array}{l}a \\
a \\
b \\
a \\
a\end{array}$ & $\begin{array}{l}42 \\
42 \\
42 \\
70 \\
70\end{array}$ & $\begin{array}{l}40 \\
40 \\
40 \\
40 \\
20\end{array}$ & $\begin{array}{r}37.0 \\
26.0 \\
5.0 \\
62.5 \\
19.8\end{array}$ & $\begin{array}{l}3.3 \\
6.8 \\
0.8 \\
8.1 \\
5.4\end{array}$ & $\begin{array}{r}10.6 \\
2.6 \\
4.6 \\
10.2 \\
11.3\end{array}$ & $\begin{array}{l}1.4 \\
2.3 \\
1.1 \\
1.2 \\
2.1\end{array}$ & $\begin{array}{l}32.0 \\
21.1\end{array}$ & $\begin{array}{l}6.0 \\
0\end{array}$ \\
\hline & & & & & \multicolumn{4}{|c|}{$\begin{array}{l}\text { Grains per } 1000 \mu \mathrm{m}^{2} \\
\text { nuclear area }\end{array}$} & \multicolumn{2}{|c|}{$\begin{array}{c}\text { Specific activity } \\
\text { grains per } 1000 \mu \mathrm{m}^{2}\end{array}$} \\
\hline & & & & & $\begin{array}{c}\text { hetero- } \\
\text { chromatin }\end{array}$ & $\begin{array}{l}\text { euchro- } \\
\text { matin }\end{array}$ & \multicolumn{2}{|c|}{$\begin{array}{l}\text { hetero- } \\
\text { euchro- } \\
\text { matin } \\
\text { border }\end{array}$} & $\begin{array}{c}\text { hetero- } \\
\text { chromatin }\end{array}$ & $\begin{array}{l}\text { euchro- } \\
\text { matin + } \\
\text { hetero- } \\
\text { euchro- } \\
\text { matin } \\
\text { border }\end{array}$ \\
\hline tip & $S_{3}$ & $\begin{array}{l}\mathrm{a} \\
\mathrm{a} \\
\mathrm{a}\end{array}$ & $\begin{array}{l}42 \\
70 \\
70\end{array}$ & $\begin{array}{l}40 \\
11 \\
20\end{array}$ & $\begin{array}{r}5.1 \\
12.5 \\
18.8\end{array}$ & $\begin{array}{r}6.2 \\
23.8 \\
28.8\end{array}$ & \multicolumn{2}{|c|}{$\begin{array}{r}4.5 \\
16.4 \\
24.0\end{array}$} & $\begin{array}{r}89 \\
218 \\
336\end{array}$ & $\begin{array}{r}8 \\
34 \\
46\end{array}$ \\
\hline middle & $S_{2}$ & $\begin{array}{l}\mathrm{a} \\
\mathrm{a} \\
\mathrm{a} \\
\mathrm{a}\end{array}$ & $\begin{array}{l}42 \\
42 \\
70 \\
70\end{array}$ & $\begin{array}{l}40 \\
40 \\
40 \\
20\end{array}$ & $\begin{array}{l}0.2 \\
0 \\
0.4 \\
0.4\end{array}$ & $\begin{array}{r}3.8 \\
0.2 \\
12.2 \\
4.2\end{array}$ & \multicolumn{2}{|c|}{$\begin{array}{r}3.4 \\
0.5 \\
10.3 \\
3.0\end{array}$} & $\begin{array}{l}0 \\
0 \\
0 \\
0\end{array}$ & $\begin{array}{r}5 \\
0 \\
15 \\
3\end{array}$ \\
\hline base & $S_{1}$ & $\begin{array}{l}\mathrm{a} \\
\mathrm{a} \\
\mathrm{a} \\
\mathrm{a}\end{array}$ & $\begin{array}{l}42 \\
42 \\
70 \\
70\end{array}$ & $\begin{array}{l}40 \\
40 \\
40 \\
40\end{array}$ & $\begin{array}{l}1.6 \\
0.5 \\
1.5 \\
1.1\end{array}$ & $\begin{array}{l}21.1 \\
13.3 \\
31.5 \\
13.2\end{array}$ & \multicolumn{2}{|c|}{$\begin{array}{l}20.8 \\
18.3 \\
35.8 \\
14.1\end{array}$} & $\begin{array}{r}15 \\
1 \\
10 \\
7\end{array}$ & $\begin{array}{l}39 \\
28 \\
66 \\
21\end{array}$ \\
\hline
\end{tabular}

DNA synthesis (Table IV). Whether synthesis becomes totally arrested during this interval remains to be determined but analyses of grain counts from individual nuclei indicate that the low levels of activity observed are due to a few nuclei and thus result from asynchrony in the meiocyte population. At the base of the anther $75-90 \%$ of the meiocytes reveal active $S_{1}$ 

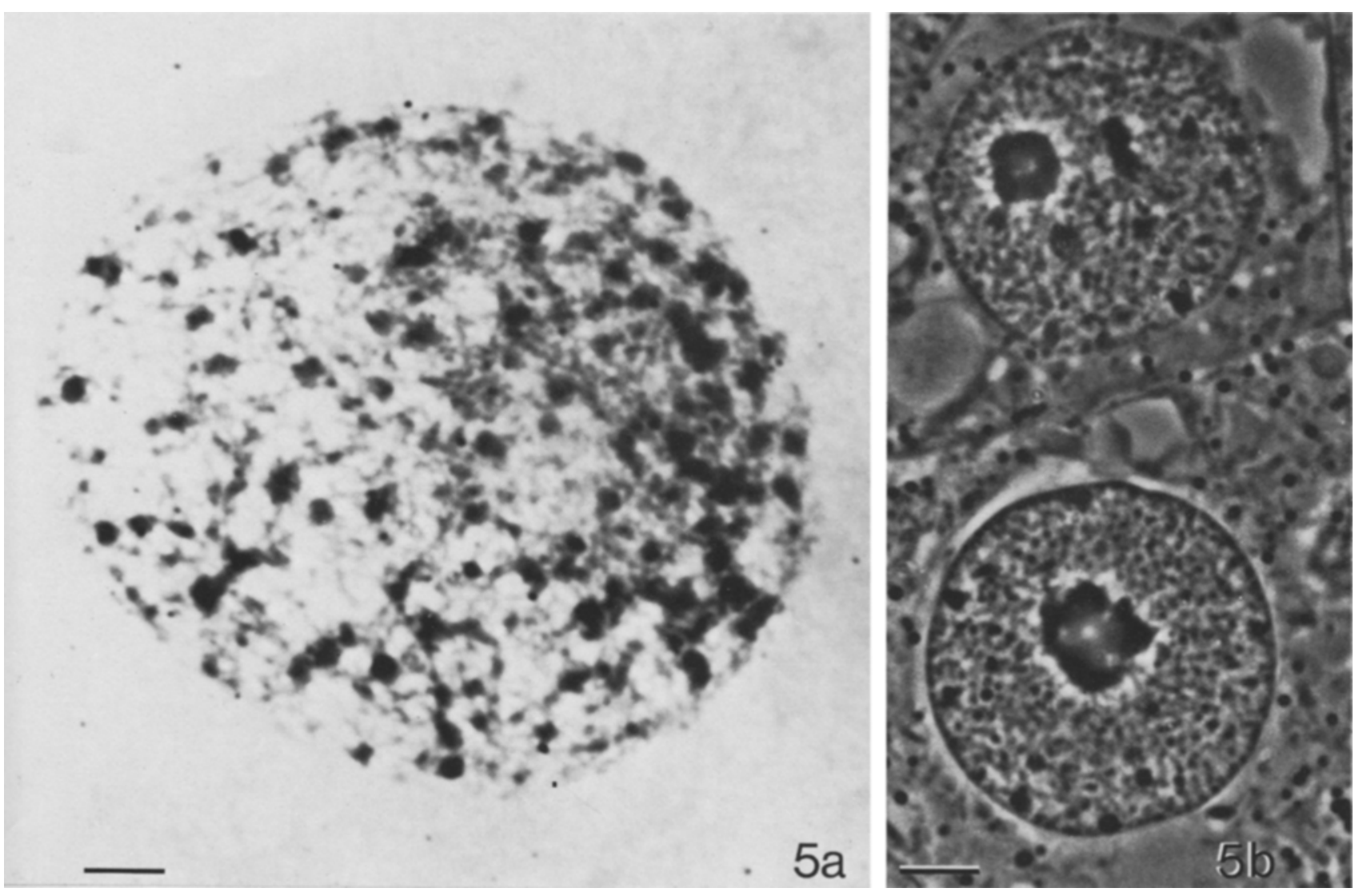

Figure 5. Labelling pattern in premeiotic $\mathrm{S}_{2}$ nuclei.

The euchromatic fibrils are more prominent than earlier and very few silver grains can be found. 5a. Survey micrograph of squashed nucleus in the $S_{2}$ stage. $\times 2000(B a r=5 \mu \mathrm{m})$. 5b. Survey micrograph of sectioned $S_{2}$ nuclei. $\times 2000(\mathrm{Bar}=5 \mu \mathrm{m})$.

replication while the remaining nuclei have low grain counts. In the mid part of the anther the reverse pattern is observed. As expected, $S_{2}$ cells may also be found in the tip of an anther (Table V).

The final phase in the premeiotic DNA replication, $S_{3}$, is characterized by the DNA synthesis in heterochromatin (Tables IV, V, Figure 6). DNase digestions reduce the radioactivity by $60-75 \%$. The majority of the grains are still recorded as euchromatic and on the border of the two chromatins, but the specific activity expressed as grains per $1000 \mu \mathrm{m}^{2}$ heterochromatin is extremely high. From both squash and section autoradiography it can be observed that most of the grains classified as positioned on the heteroeuchromatic border are located on strands and loops extending out from the chromocenters. Clusters of grains over balls of fibrillar chromatin are evident (Figure 6). These observations indicate that heterochromatin is less compacted during replication and re-condensed after replication is completed. The activity recorded as DNA synthesis in heterochromatin is accordingly an underestimate.

The DNA replication continues unchanged through the $S_{3}$ period and is terminated at the beginning of early leptotene (Table V). Replication may extend into the first quarter of this period. No evidence for DNA synthesis in mid 
Table V

Incorporation of thymidine-6- ${ }^{3} \mathrm{H}$ into meiocytes. Grain counts from 2 hours pulse labelled anther halves. Procedures: a, resin sections ; b, DNase treatment.

\begin{tabular}{|c|c|c|c|c|c|c|c|c|c|c|}
\hline \multirow[t]{2}{*}{$\begin{array}{l}\text { Anther } \\
\text { portion }\end{array}$} & \multirow[t]{2}{*}{ Stage } & \multirow[t]{2}{*}{$\begin{array}{l}\text { Proce- } \\
\text { dure }\end{array}$} & \multirow{2}{*}{$\begin{array}{l}\text { Expo- } \\
\text { sure } \\
\text { days }\end{array}$} & \multirow{2}{*}{$\begin{array}{l}\text { Sec- } \\
\text { tions } \\
\text { counted }\end{array}$} & \multicolumn{4}{|c|}{$\begin{array}{l}\text { Grains per } 1000 \mu \mathrm{m}^{2} \\
\text { minus background }\end{array}$} & \multicolumn{2}{|c|}{$\begin{array}{c}\text { DNase sensitive } \\
\text { grains per } 1000 \mu \mathrm{m}^{2}\end{array}$} \\
\hline & & & & & nucleus & $\mathrm{SE}$ & $\begin{array}{l}\text { cyto- } \\
\text { plasm }\end{array}$ & $\overline{\mathrm{SE}}$ & nucleus & $\begin{array}{l}\text { cyto- } \\
\text { plasm }\end{array}$ \\
\hline tip & $\begin{array}{l}\text { early-mid } \\
\text { leptotene }\end{array}$ & a & 60 & 32 & 0 & & 1.2 & 1.5 & & \\
\hline tip & $\begin{array}{l}\text { early } \\
\text { leptotene }\end{array}$ & $\mathrm{a}$ & 60 & 36 & 3.5 & 1.3 & 2.9 & 1.2 & & \\
\hline $\begin{array}{l}\text { middle } \\
\text { base } \\
\text { base } \\
\text { tip } \\
\text { middle } \\
\text { middle } \\
\text { base } \\
\text { base }\end{array}$ & $\begin{array}{l}S_{3} \\
S_{3} \\
S_{3} \\
S_{2} \\
S_{2} \\
S_{1} \\
S_{1} \\
S_{1}\end{array}$ & $\begin{array}{l}a \\
a \\
b \\
a \\
b \\
a \\
b \\
a\end{array}$ & $\begin{array}{l}60 \\
60 \\
60 \\
60 \\
60 \\
60 \\
60 \\
60\end{array}$ & $\begin{array}{l}33 \\
40 \\
18 \\
40 \\
17 \\
40 \\
20 \\
26\end{array}$ & $\begin{array}{r}15.3 \\
14.2 \\
2.0 \\
7.4 \\
5.9 \\
24.6 \\
6.0 \\
11.6\end{array}$ & $\begin{array}{l}1.9 \\
2.4 \\
1.7 \\
1.6 \\
2.8 \\
3.7 \\
1.8 \\
1.8\end{array}$ & $\begin{array}{l}3.3 \\
8.7 \\
0 \\
0 \\
3.7 \\
0 \\
12.7 \\
0.8\end{array}$ & $\begin{array}{l}2.1 \\
1.8 \\
1.3\end{array}$ & $\begin{array}{r}13.3 \\
12.2 \\
1.5 \\
18.6\end{array}$ & $\begin{array}{l}3.3 \\
8.7 \\
0 \\
0\end{array}$ \\
\hline \multirow{2}{*}{ base } & & & & & \multicolumn{4}{|c|}{$\begin{array}{c}\text { Grains per } 1000 \mu \mathrm{m}^{2} \\
\text { nuclear area }\end{array}$} & \multicolumn{2}{|c|}{$\begin{array}{c}\text { Specific activity } \\
\text { grains per } 1000 \mu \mathrm{m}\end{array}$} \\
\hline & & & & & $\begin{array}{l}\text { hetero- } \\
\text { chromatin }\end{array}$ & $\begin{array}{l}\text { euchro } \\
\text { matin }\end{array}$ & $\begin{array}{l}\text { hete } \\
\text { euch } \\
\text { mat } \\
\text { bord }\end{array}$ & & $\begin{array}{c}\text { hetero- } \\
\text { chromatin }\end{array}$ & $\begin{array}{l}\text { euchro- } \\
\text { matin + } \\
\text { hetero- } \\
\text { euchro- } \\
\text { matin } \\
\text { border }\end{array}$ \\
\hline tip & $\begin{array}{l}\text { early } \\
\text { leptotene }\end{array}$ & $\mathrm{a}$ & 60 & 36 & 2.0 & 6.2 & 1. & & 31 & 2 \\
\hline middle & $\mathrm{S}_{3}$ & a & 60 & 33 & 6.6 & 15.8 & 4 & & 72 & 10 \\
\hline base & $S_{3}$ & $\mathbf{a}$ & 60 & 40 & 4.0 & 15.3 & 5 & & 60 & 12 \\
\hline tip & $\mathrm{S}_{3}$ & $b$ & 60 & 18 & 1.3 & 5.8 & 1 & & 16 & 1 \\
\hline tip & $\mathrm{S}_{2}$ & $\mathrm{a}$ & 60 & 40 & 1.0 & 13.3 & 3 & & 10 & 7 \\
\hline middle & $\mathrm{S}_{2}$ & b & 60 & 17 & 0.5 & 19.9 & 4 & & 0 & 7 \\
\hline middle & $S_{1}$ & a & 60 & 40 & 0.1 & 23.0 & 12 & & 0 & 27 \\
\hline base & $S_{1}$ & b & 60 & 20 & 0 & 16.8 & 4 & & 0 & 6 \\
\hline base & $S_{1}$ & a & 60 & 26 & 0.2 & 10.7 & 5 & & 0 & 13 \\
\hline
\end{tabular}

and late leptotene has been obtained.

A summary of results from five buds spanning the interval of DNA replication is presented in Table VI from which it is concluded that the premeiotic $S$ phase consists of two approximately equally long intervals of

Figure 6. Labelling pattern in premeiotic $S_{3}$ nuclei.

The euchromatic chromatin fibrils are clearly defined and many silver grains are located on or close to the chromocenters. The chromocenters are looser than in earlier stages and appear as fibrillar balls. 6a, Survey micrograph of squashed nucleus in the $S_{3}$ stage. $\times 2000(B a r=5 \mu \mathrm{m}) .6 \mathrm{~b}-\mathrm{c}$. Survey micrographs of sectioned nuclei in the $S_{3}$ stage. $\times 2000(B a r=5 \mu \mathrm{m}) .6$ d. Detail of squashed nucleus in the $S_{3}$ stage. $\times 4000(B a r=2 \mu \mathrm{m}) .6 \mathrm{e}$. Detail of squashed nucleus in the $S_{3}$ stage. $\times 6000(B a r=2 \mu \mathrm{m})$. 
2. $30.68 \%$

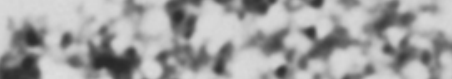

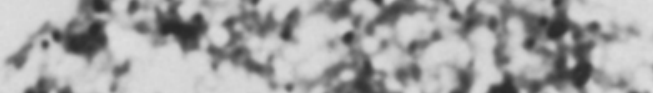

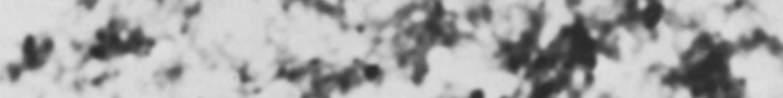

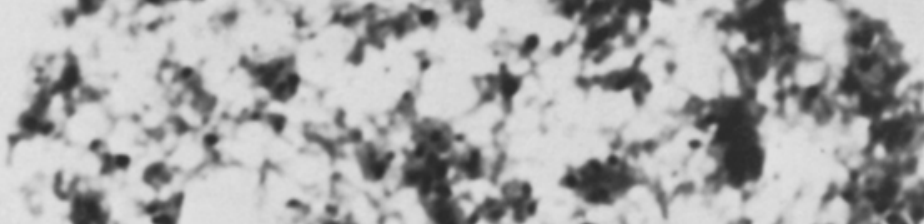

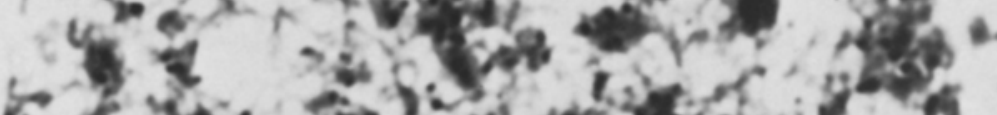

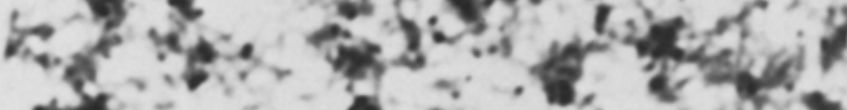

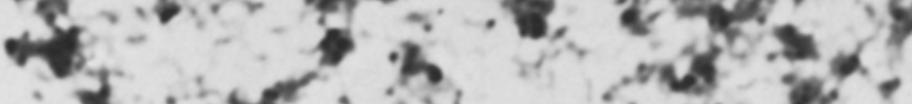

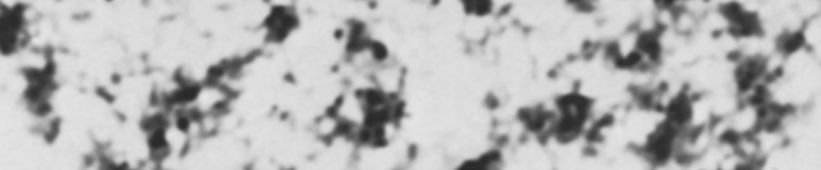

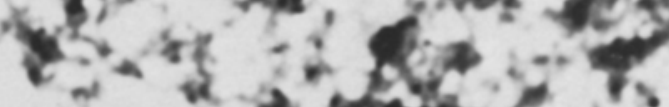

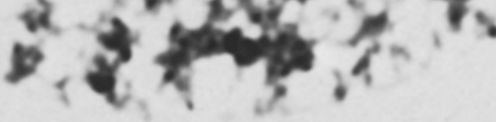

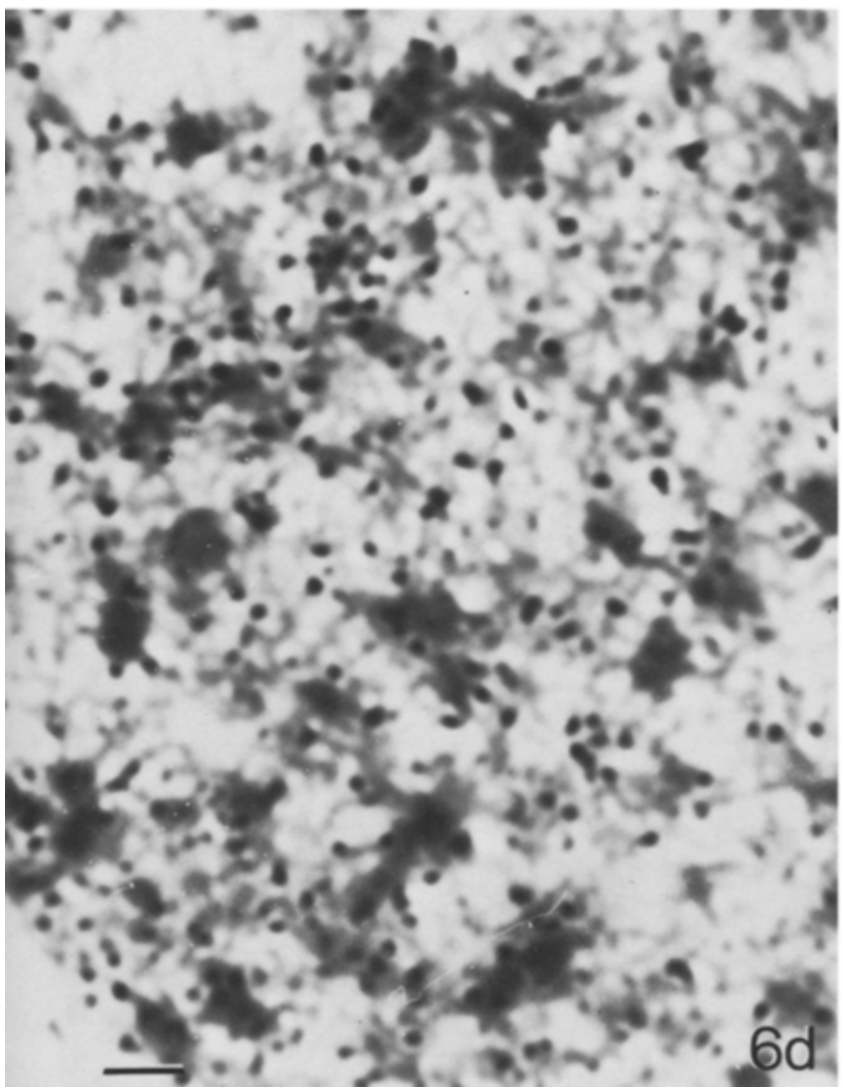

$6 \mathrm{a}$

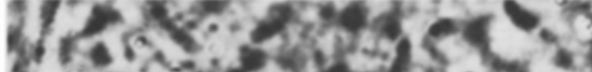

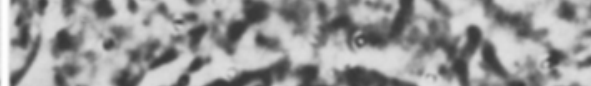

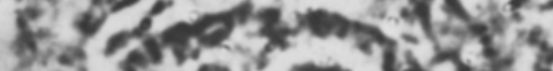

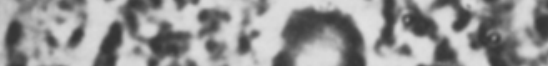

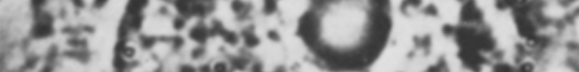

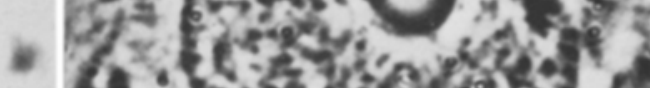

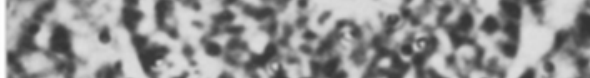

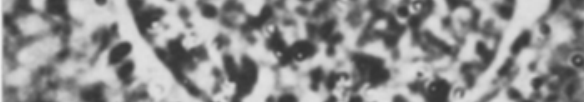

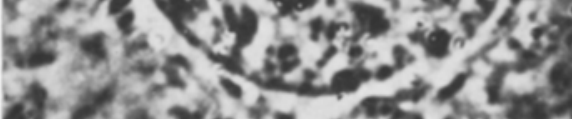

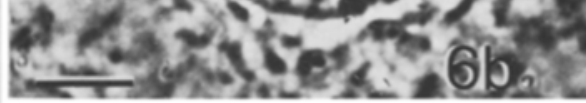
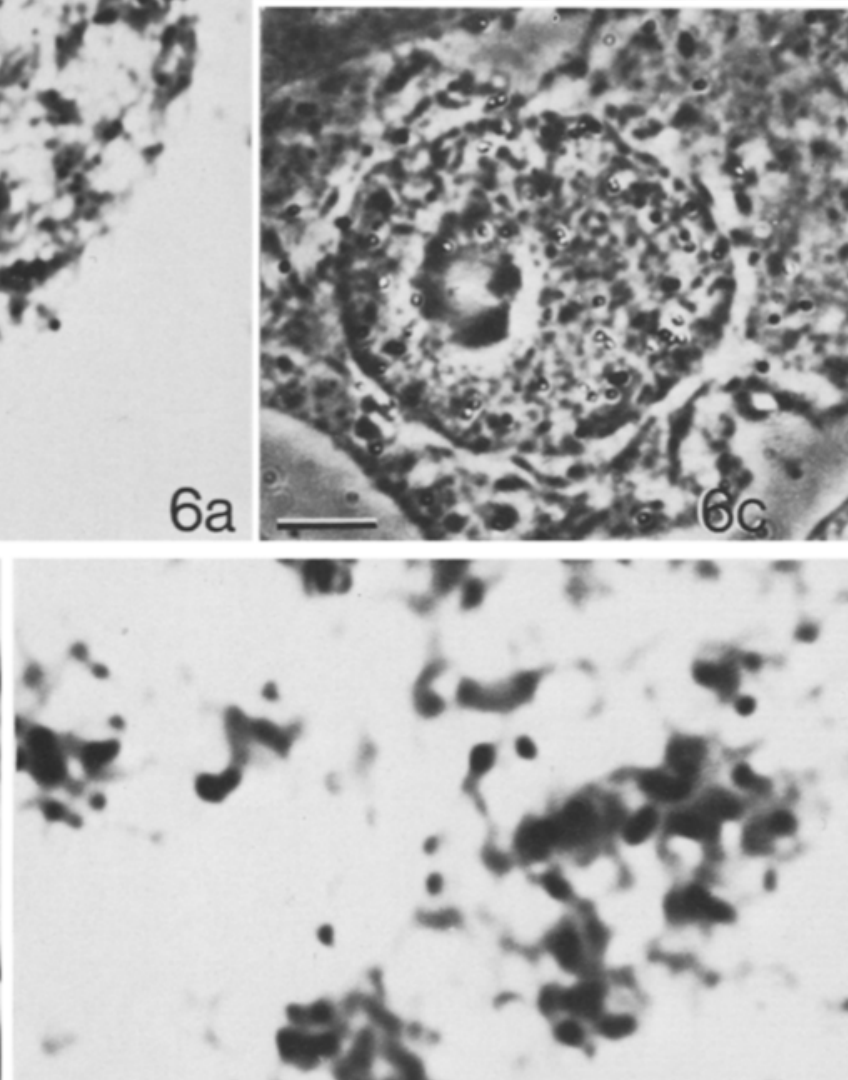

\footnotetext{
.
}

2.

4

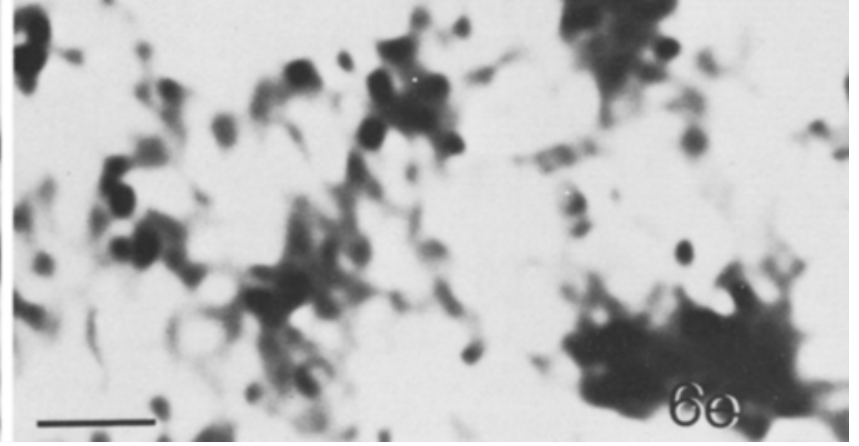


Table VI

DNA synthesis in the different chromatin fractions during the substages of the premeiotic $S$ phase. Summary of data from five buds.

I) Squash preparation corrected to an exposure time of 70 days

II) Squash preparations from the $\mathbf{4 2}$ days exposure series

III) Sectioned material

Total synthesis in the different chromatin fractions during the substages of the premeiotic $S$ phase was calculated as follows: Grain counts were corrected for background on the basis of the area measurements and the total synthesis calculated for each substage and chromatin fraction with normalization for the pulse time and the estimated duration of the particular stage. It is assumed that DNA replication extends into the first quarter of early leptotene.

\begin{tabular}{|c|c|c|c|c|}
\hline Stage & $\begin{array}{l}\text { duration } \\
\text { hours }\end{array}$ & $\begin{array}{l}\text { DNA synthesis in } \\
\text { heterochromatin } \\
\%\end{array}$ & $\begin{array}{l}\text { DNA synthesis in } \\
\text { euchromatin + } \\
\text { hetero-euchro- } \\
\text { matin border }\end{array}$ & $\begin{array}{l}\text { total DNA } \\
\text { synthesis } \%\end{array}$ \\
\hline$S_{1}$ & 18 & $\begin{array}{rrr}\text { I } & \text { II } & \text { III } \\
2 & 2 & 0\end{array}$ & $\begin{array}{ccc}\text { I } & \text { II } & \text { III } \\
47 & 54 & 52\end{array}$ & $\begin{array}{ccc}\text { I } & \text { II } & \text { III } \\
37 & 40 & 43\end{array}$ \\
\hline $\mathrm{S}_{2}$ & 9 & $\begin{array}{lll}1 & 2 & 4\end{array}$ & $\begin{array}{lll}4 & 4 & 10\end{array}$ & $\begin{array}{lll}3 & 4 & 9\end{array}$ \\
\hline $\begin{array}{l}\mathrm{S}_{3}+\text { early } \\
\text { leptotene }\end{array}$ & 22.5 & $\begin{array}{lll}97 & 96 & 96\end{array}$ & $\begin{array}{lll}49 & 42 & 38\end{array}$ & $\begin{array}{lll}60 & 56 & 48\end{array}$ \\
\hline & & \multicolumn{2}{|c|}{$\begin{array}{ll} & \begin{array}{c}\text { \% of total synthesis } \\
23\end{array} 28 \quad 17\end{array}$} & \\
\hline
\end{tabular}

DNA synthesis which are separated by a period with little or no DNA synthesis. Virtually all DNA compacted into chromocenters is replicated late. Grains over heterochromatin comprise on the average at least $23 \%$ of the total (Table VI). As mentioned above, it is likely however that a major fraction if not all of the synthesis recorded in euchromatin at $S_{3}$ actually represents DNA synthesis in newly dispersed heterochromatin. Likewise the synthesis recorded for the hetero-euchromatic border at $\mathrm{S}_{3}$ is considered to represent heterochromatic replication. Thus all of the 50 to $60 \%$ of DNA replicated at $S_{3}$ may be assigned to heterochromatin.

A major problem in the investigation of the premeiotic DNA replication has been the metabolization and the low uptake of the thymidine. In an attempt to improve the conditions, thymine was introduced as a tracer of DNA synthesis. The same replication pattern could be observed, but the activity was only $10-20 \%$ of the activity recorded for thymidine. Moreover thymine is also degraded and reused, necessitating large scale DNase controls.

\subsection{Volume of heterochromatin in premeiotic nuclei}

In order to provide a better understanding of the replication events the heterochromatin volume has been estimated for presynaptic nuclei. The results obtained support the qualitative morphological observations (Figure 7). The slight increase in volume observed between $G_{1}$ and $S_{1}$ has been found reproducibly and might reflect either the DNA replication in the peripheral parts of chromocenters or additional heterochromatin. In the $S_{3}$ nuclei the volume of heterochromatin is found to be the same as in $S_{1}$ and $S_{2}$ nuclei. One might have expected an increase in the average volume of heterochromatin, signifying its replication. The observed decondensation of the heterochromatin during replication might lead to an underestimate of the volume of replicating chromocenters and compensate for the volume increase in chromocenters already replicated.

At early leptotene the heterochromatin has doubled in volume compared to $S_{1}$. The very large range in the distribution of the volumes indicate that replication in heterochromatin is 
P. B. HoLm: Premeiotic DNA replication in Lilium

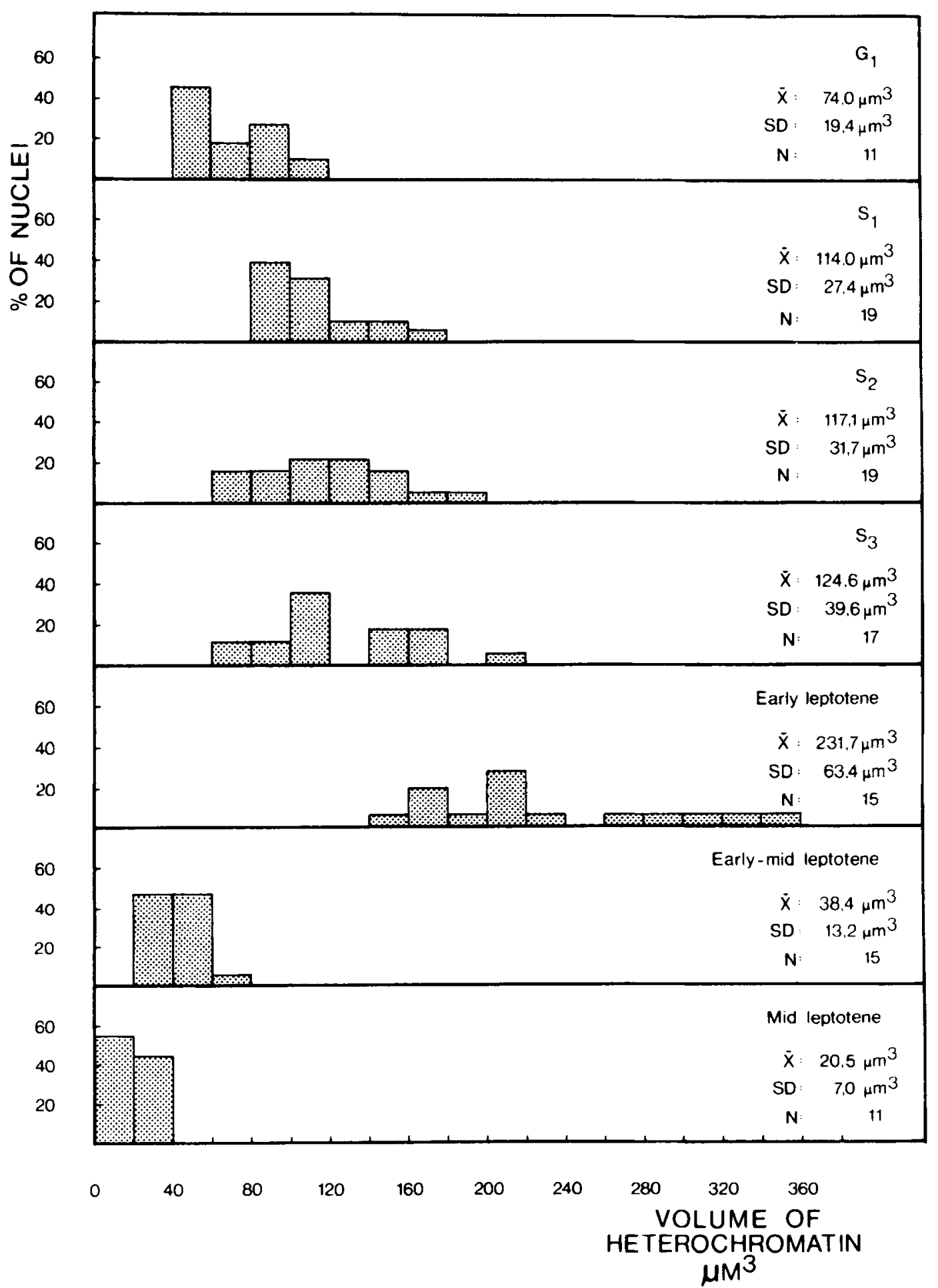

Figure 7. Volume of heterochromatin in premeiotic nuclei. Volume calculations were carried out as described under Methods, section 2.8.

$\mathrm{SD}$, standard deviation. $\mathrm{N}$, number of nuclei 

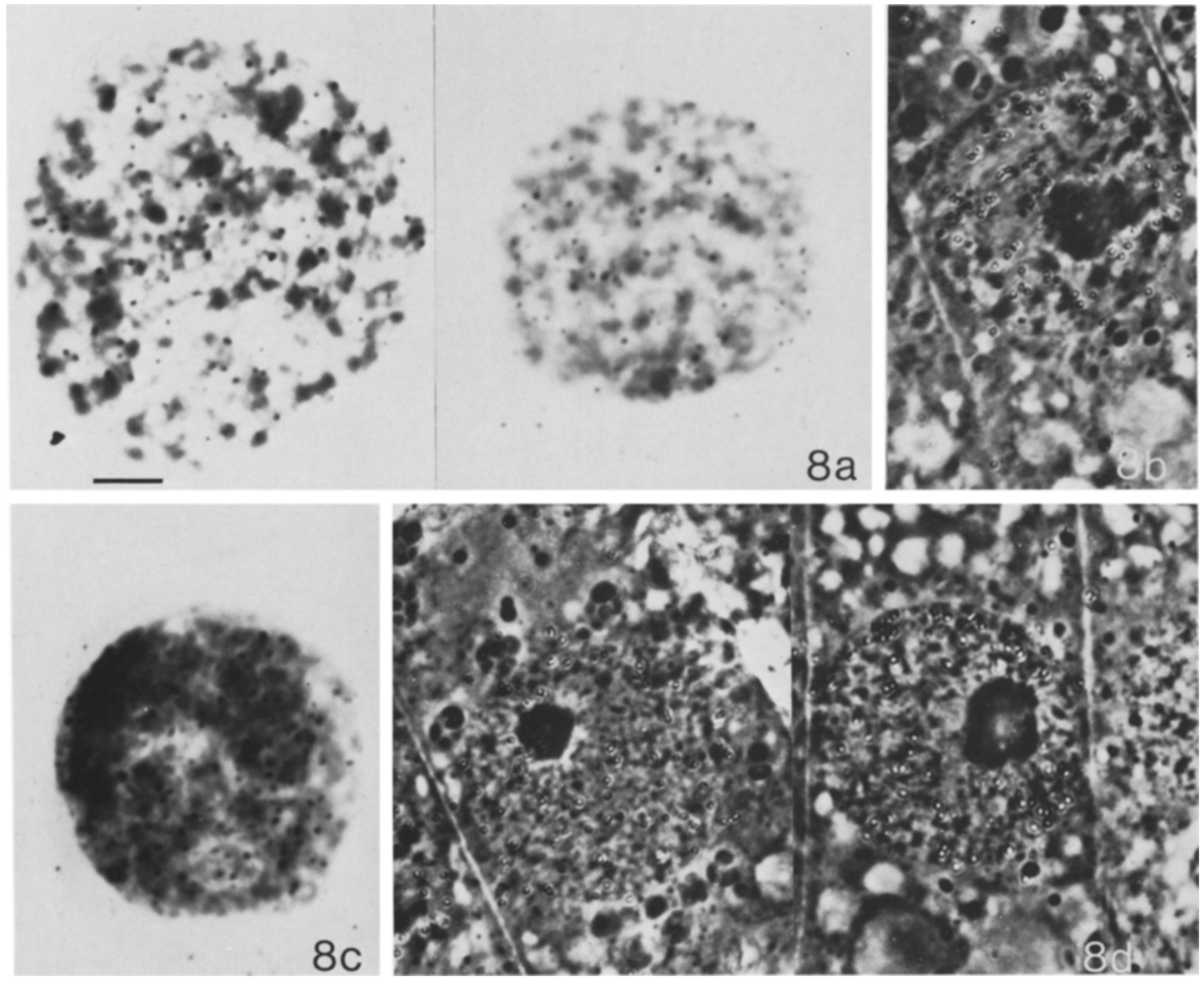

Figure 8. Labelling patterns in root tip nuclei.

In the nuclei of $8 \mathrm{a}$ and $\mathrm{b}$ the silver grains are located above the euchromatin $\left(\mathrm{S}_{1}\right.$ stage). The nuclei in Figures $8 \mathrm{c}$ and $d$ illustrate groups of grains above or close to the heterochromatin, $S_{3}$ stage. $8 \mathrm{a}+\mathrm{c}$. Squashed root tip nuclei. $\times 2000(\mathrm{Bar}=5 \mu \mathrm{m}) .8 \mathrm{~b}+\mathrm{d}$. Sectioned root tip nuclei. $\times 2000(\mathrm{Bar}=5 \mu \mathrm{m})$.

still going on. It cannot be excluded however that some of the increment in chromocenter size is due to additional condensation of regions being euchromatic during the preceding intervals. The disappearance of the heterochromatin during mid leptotene can also be quantitatively assessed. In late leptotene virtually no heterochromatin can be identified besides a few nucleolus associated knobs.

An interesting result obtained from the volume measurements is the very large variation in the amount of heterochromatin between synchronous nuclei. Variations in volume of $100-200 \%$ are not due to errors, but must reflect native variations in chromatin compaction between the nuclei. 
Table VII

Grain counts from $\mathrm{S}$ phase nuclei in the root tip. Five mm long root tips were labelled for 30 minutes with $5 \mu \mathrm{Ci} / \mathrm{ml}$ thymidine- $6-{ }^{-} \mathrm{H}$. The specific activity of the chromatin fractions was calculated from the area measurements of heterochromatin and euchromatin. The very low background was ignored.

\begin{tabular}{|c|c|c|c|c|c|c|c|}
\hline \multirow[t]{2}{*}{ Stage } & \multirow{2}{*}{$\begin{array}{l}\text { Exposure } \\
\text { days }\end{array}$} & \multirow{2}{*}{$\begin{array}{l}\text { Nuclei } \\
\text { counted }\end{array}$} & \multicolumn{5}{|c|}{ Grains over } \\
\hline & & & Nucleus & SE & $\begin{array}{l}\text { Hetero- } \\
\text { chromatin }\end{array}$ & Euchromatin & $\begin{array}{c}\text { Hetero-euchromatin } \\
\text { border }\end{array}$ \\
\hline$S_{1}$ & 30 & 102 & 39.8 & 2.0 & 0.8 & 23.9 & 15.2 \\
\hline \multirow[t]{3}{*}{$\mathrm{S}_{3}$} & 30 & 98 & 47.1 & 2.1 & 10.5 & 23.8 & 12.8 \\
\hline & & & \multicolumn{5}{|c|}{ Specific activity grains per $1000 \mu \mathrm{m}^{2}$} \\
\hline & & & \multicolumn{3}{|c|}{ Heterochromatin } & \multicolumn{2}{|c|}{$\begin{array}{l}\text { Euchromatin }+ \\
\text { hetero-euchromatin border }\end{array}$} \\
\hline $\mathrm{S}_{\mathrm{l}}$ & 30 & 102 & \multicolumn{3}{|c|}{11} & \multicolumn{2}{|r|}{84} \\
\hline $\mathrm{S}_{3}$ & 30 & 98 & \multicolumn{3}{|c|}{131} & \multicolumn{2}{|r|}{71} \\
\hline
\end{tabular}

\subsection{Somatic DNA replication}

The duration of somatic $S$ phases were calculated according to the method of QUASTLER and SHERMAN (56). The percentage of labelled metaphases was plotted against the duration of the chase. The plot resulted in a single broad peak. The mean duration of the $S$ phase is defined as the width of the peak at $50 \%$ labelled metaphases. A duration of 8 hours was obtained. Considering that variation in $S$ phase between different tissues of the root tip has been found in other organisms investigated (15), it is reasonable to conclude that DNA replication in root tip nuclei of Lilium lasts between 6 and 12 hours. Pulse-labelling of root tip nuclei was performed for comparison of the premeiotic and the somatic $S$ phase. The pulse applied to the premeiotic system covers $4 \%$ of the $S$ phase and that applied to the somatic cells $6 \%$ of the replication period. The labelling patterns should thus be directly comparable.

Root tip nuclei in $\mathrm{S}$ phase share some morphological characteristics with the premeiotic nuclei (Figures 8,14 ). They contain prominent heterochromatin lumps and the euchromatin consists of fine fibrils. DNA replication seems also in this case to be initiated in the euchromatin and in the border regions between

\section{Table VIII}

DNA synthesis in the different chromatin fractions during the somatic $S$ phase. The calculations were performed as described in Table VI, assuming an equal length of the $S_{1}$ and the $S_{3}$ period.

\begin{tabular}{c|c|c|c}
\hline Stage & $\begin{array}{c}\text { DNA synthesis } \\
\text { in hetero- } \\
\text { chromatin } \\
\%\end{array}$ & $\begin{array}{c}\text { DNA synthesis } \\
\text { in euchro- } \\
\text { matin }+ \\
\text { hetero-euchro- } \\
\text { matin border \% }\end{array}$ & $\begin{array}{c}\text { Total DNA } \\
\text { synthesis } \\
\%\end{array}$ \\
\hline $\mathrm{S}_{1}$ & 7 & 52 & 46 \\
\hline $\mathrm{S}_{3}$ & 93 & 48 & 54 \\
\hline
\end{tabular}

euchromatin and heterochromatin (Figures 8a, c) since in one group of nuclei the grains are found preferentially located over the euchromatin. In another group of nuclei the grains are preferentially located over the chromocenters signifying its replication. As in the premeiotic $S_{3}$ stage this replication is correlated with a decondensed morphology of the heterochromatin (Figures $8 \mathrm{~b}, \mathrm{~d}$ ). No indication of a stage without grains comparable to the premeiotic $S_{2}$ interval was obtained.

The radioactivity of 200 nuclei selected at 


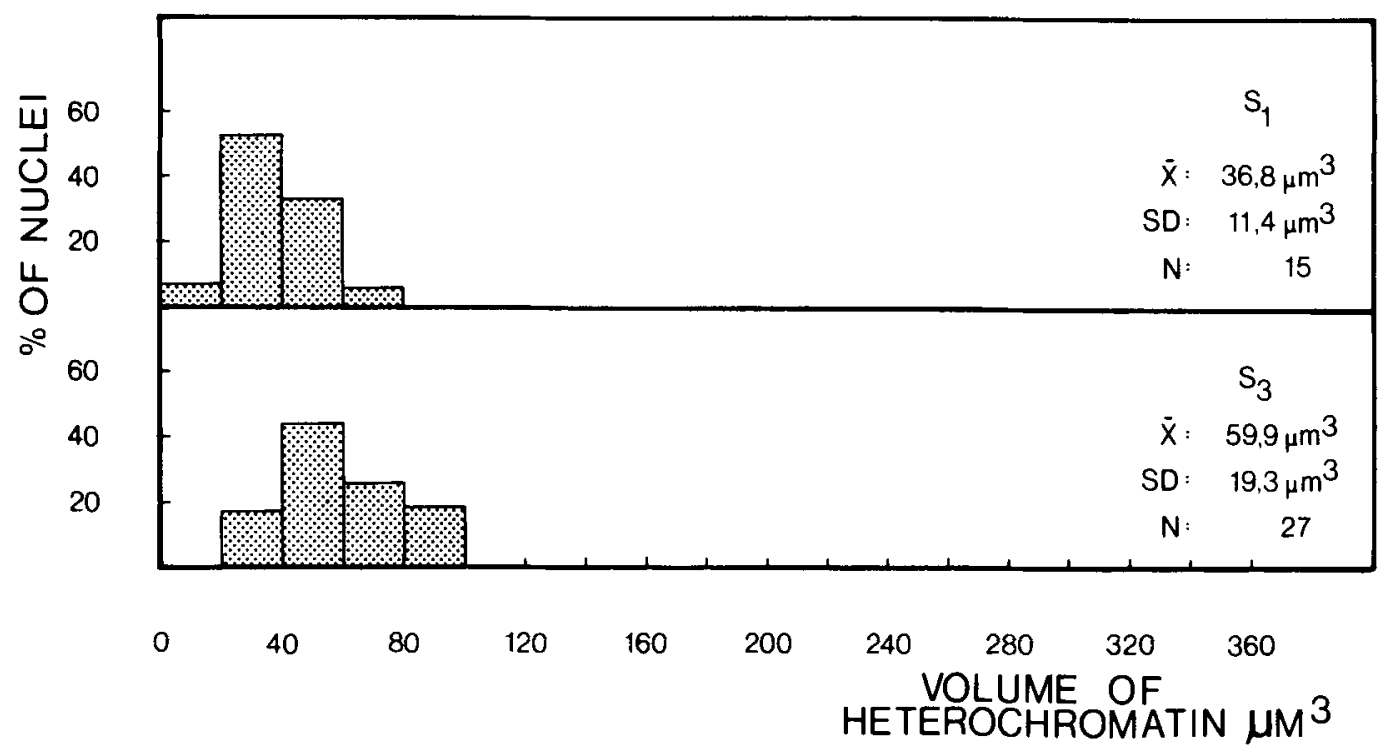

Figure 9. Volume of heterochromatin in root tip nuclei. Nuclei displaying $S_{1}$ and $S_{3}$ types of replication patterns were photographed and volume calculations carried out as described under Methods, section 2.8. SD, standard deviation. $\mathrm{N}$, number of nuclei

random was recorded and grain counts specified for the different chromatin fractions (Table VII). Approximately $50 \%$ of the nuclei were showing radioactivity in heterochromatin, $50 \%$ only in euchromatin and heteroeuchromatic borders. Assuming that the cell populations of the root tip are asynchronous, the two substages of the somatic $S$ phase are of equal duration. The amounts of DNA synthesis in the different chromatin fractions have been calculated using the area measurements and are given in Table VIII. The results suggest that $50 \%$ of the total DNA synthesis takes place in nuclei which reveal delayed DNA replication in heterochromatin. Moreover it can be calculated from the data in Table VIII that $13 \%$ of the activity is recorded over heterochromatin. As for the premeiotic $S$ phase this figure should be considered as a minimum value for the amount of DNA located in heterochromatin. Preliminary experiments have demonstrated that if $S_{3}$ nuclei are chased for 8 hours, $23 \%$ of the silver grains are localized over heterochromatin of the $\mathrm{G}_{2}$ nuclei.

\subsection{Volume of heterochromatin in somatic nuclei}

Concomitantly with performing the grain counts somatic nuclei showing the $S_{1}$ and $S_{3}$ type of replication pattern were photographed and the heterochromatin volume calculated as described in section 2.8. As evident from Figure 9 , heterochromatin in somatic nuclei is $2-3$ times lower than in the premeiotic nuclei.

\subsection{The premeiotic and somatic DNA replication in comparison}

The differences between the two types of DNA replication can be summarized as follows:

Figure 10. Root tip nuclei stained with the Giemsa $C$ (III) procedure. Nuclei displaying $G_{1}-S_{1}, S_{3}$ and $G_{2}$ characteristics are indicated. Giemsa bands on metaphase and prophase chromosomes are included for comparison. The $G_{1}-S_{1}$ nucleus is characterized by small Giemsa stained chromocenters and smoothly distributed chromatin. The $S_{3}$ nucleus has prominent euchromatin and few Geimsa stained chromocenters, whereas the $G_{2}$ nucleus contains large Giemsa stained chromocenters.

$10 \mathrm{a}-\mathrm{b} . \times 2000(\mathrm{Bar}=5 \mu \mathrm{m})$ 


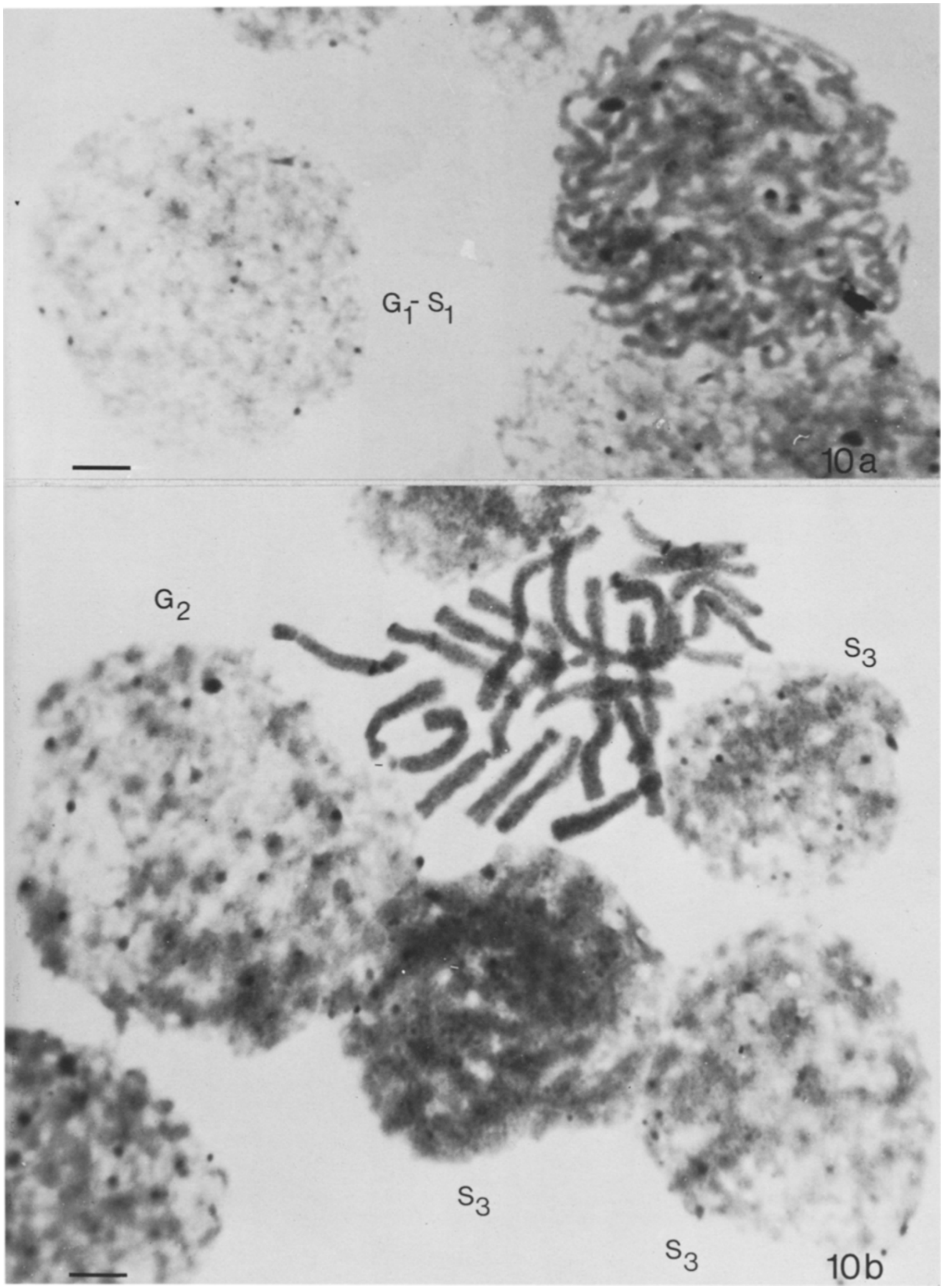


1. The premeiotic $S$ phase lasts 50 hours versus 8 hours for the somatic S phase. It is thus 6 times longer.

2. The amount of DNA packed into chromocenters in premeiotic nuclei $\left(114 \mu \mathrm{m}^{3}\right)$ is two-three fold higher than in somatic $S$ phase nuclei $\left(37 \mu \mathrm{m}^{3}\right) .50-60 \%$ of the replication events in the premeiotic nuclei is associated with heterochromatin.

3. A distinct phase with low or no DNA synthesis lasting a minimum of 9 hours separates the two major replication periods in the premeiotic $\mathbf{S}$ phase. Such a gap is not recognizable in the middle of the somatic $S$ phase.

\subsection{Giemsa $C$ staining of interphase nuclei}

In an attempt to characterize further the transient premeiotic heterochromatin, Giemsa $\mathrm{C}$ and quinacrine mustard banding procedures have been applied. The banding patterns of the karyotype have been presented previously (26). Good morphological preservation and distinct $\mathrm{C}$ banding were observed with procedure III

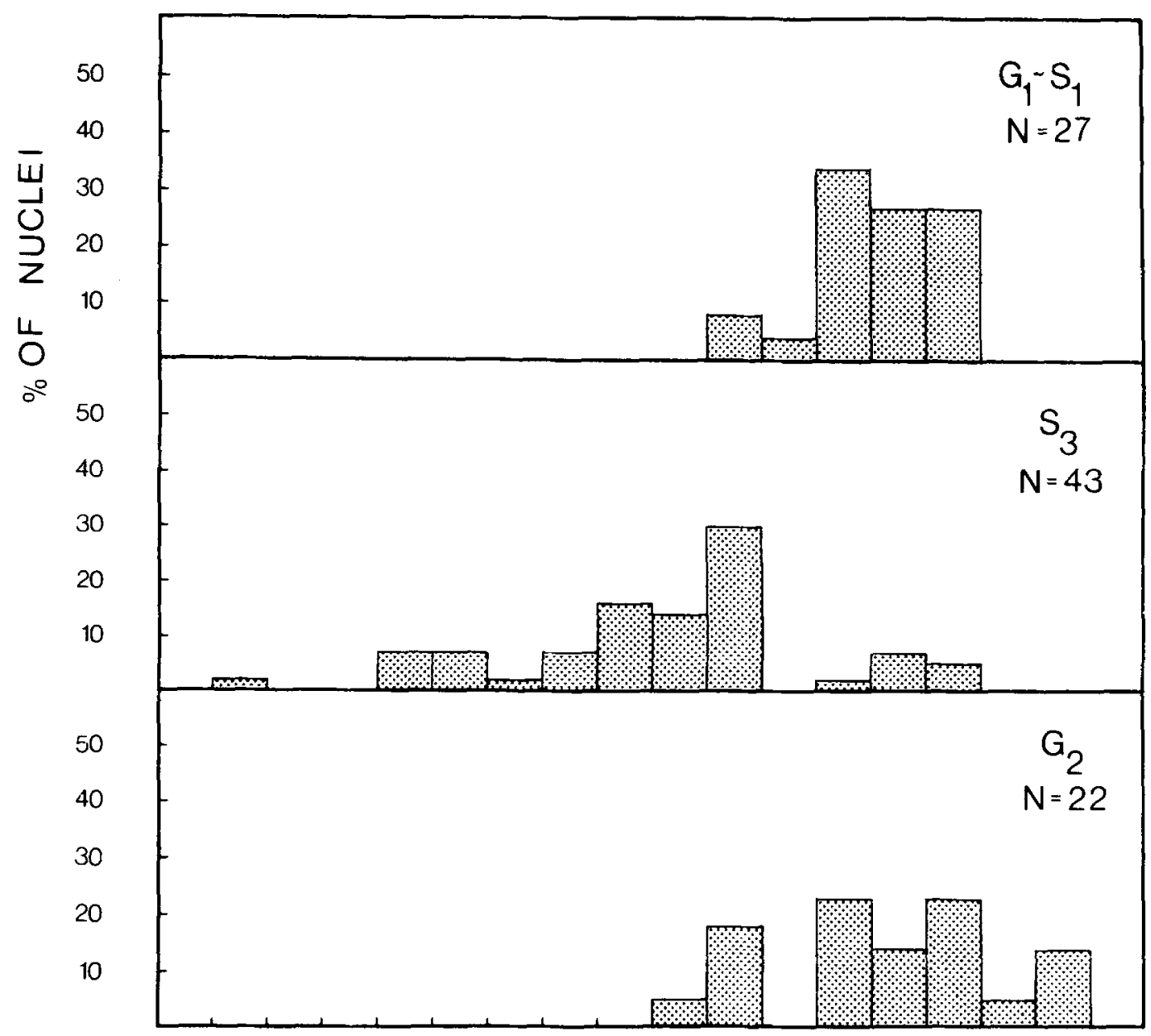

$\begin{array}{llllllllllllllll}5 & 6 & 7 & 8 & 9 & 10 & 11 & 12 & 13 & 14 & 15 & 16 & 17 & 18 & 19 & 20\end{array}$ NO.OF CHROMOCENTERS

Figure 11. Histogram illustrating the number of Giemsa $C$ stained chromocenters in root tip nuclei. For definition of the stages see section 3.9 and Figure 10. N, number of nuclei. 
(see section 2.9). Using this method nuclei from root tips could be separated into three major groups (Figure 10). One displaying several small, distinct chromocenters and smoothly distributed chromatin is considered as stage $G_{1}-S_{1}$. Another group with prominent euchromatin and few chromocenters is interpreted as $\mathrm{S}_{3}$ whereas the third group with several large sometimes double chromocenters is regarded as $\mathrm{G}_{2}$ stage.

Giemsa $\mathrm{C}$ stained nuclei in squashes were photographed at random, classified as defined above and the number of chromocenters counted (Figure 11). The Lilium longiflorum karyotype possess nine major $\mathrm{C}$ bands. Besides, tiny $\mathrm{C}$ bands have been observed in and around the centromere region, but in an inconsistent way (26). If $\mathrm{C}$ bands correspond to heterochromatin as defined by HEITZ (22), 18 major Giemsa $\mathrm{C}$ stained chromocenters should be evident in $G_{1}$ and $G_{2}$ nuclei. The data reported in Figures 10 and 11 support this notion, the $G_{1}$ and $G_{2}$ nuclei containing between 14 and 18 Giemsa $C$ stained chromocenters. The minor reduction in the average number could be due to fusion, but the alternative possibility, that a few of the $\mathrm{C}$ banded regions have decondensed during $G_{1}-S_{1}$ and $G_{2}$ cannot be excluded. The presence of 19 or 20 chromocenters in some $G_{2}$ nuclei could reflect the occasional occurence of $\mathrm{C}$ bands in and around the centromere region.

The number of Giemsa stained chromocenters in the nuclei classified as $S_{3}$ is reduced as compared to earlier and later stages. As the chromocenter's DNA replicates during the $S_{3}$ interval the reduction in Giemsa stained chromocenters is regarded as a loss of Giemsa $\mathrm{C}$ staining capacity during replication in agreement with the decondensation of chromocenters observed in these nuclei. Due to limited amounts of material it has not been possible to investigate the banding characteristics of premeiotic nuclei and archesporial metaphase chromosomes to the same extent as for root tips. Only procedure II (section 2.9) has been used, and no quantitative data are therefore reported. The banding pattern of colchicine treated metaphase chromosomes in anthers was similar to the pattern observed in root tip chromosomes, and a reduction in the number of Giemsa stained chromocenters during premeiotic $S_{3}$ has been observed. The number of Giemsa $\mathrm{C}$ stained chromocenters was of the same order of magnitude for premeiotic $G_{1}$ and $S_{1}$ as for somatic $G_{1}-S_{1}$.

\subsection{Quinacrine mustard staining of interphase nuclei}

The number of $Q$ bands observed in the chromosomes of Lilium longiflorum is very high; $40-50 \%$ of the chromosome volume has been observed to be fluorescent after quinacrine mustard staining (26). Moreover only one $\mathrm{C}$ banded region of the chromosomes demonstrates reduced fluorescense. The abundance of $\mathrm{Q}$ bands and the low number of $\mathrm{C}$ bands in Lilium longiflorum chromosomes has recently been confirmed by KONGSUWAN and SMYTH (40). As an initial approach the $Q$ banding patterns of colchicine treated archesporial metaphase chromosomes were investigated. No difference has been observed between in $\dot{Q}$ band pattern of the chromosomes in the anther tissue and those from root tips in a series of buds ranging in size from 2-3 $\mathrm{mm}$ to $9.5 \mathrm{~mm}$.

The fluorescence patterns of interphase nuclei after staining with quinacrine mustard have been investigated for all stages from early archesporial development to late leptotene. The slides were post-stained with orcein to permit a comparison with the pattern of chromocenters revealed by the latter technique. The dynamic changes in amount and distribution of heterochromatin previously described during $S_{3}$ and leptotene are especially evident in these preparations (Figure 12). Little heterochromatin is observed during the $S_{3}$ phase (Figures $12 \mathrm{a}, \mathrm{b}$ ). The heterochromatin is again promintly condensed at early leptotene (Figures $12 \mathrm{c}, \mathrm{d}$ ). In late leptotene very little fluorescent heterochromatin can be observed in parallel with the few remaining heterochromatic lumps visible by orcein staining on the chromosomes. Fluorescence and staining intensity with orcein is closely parallel when comparing individual chromocenters. Area calculations from a population of $\mathrm{S}_{2}$ nuclei are presented in Table IX. In the 


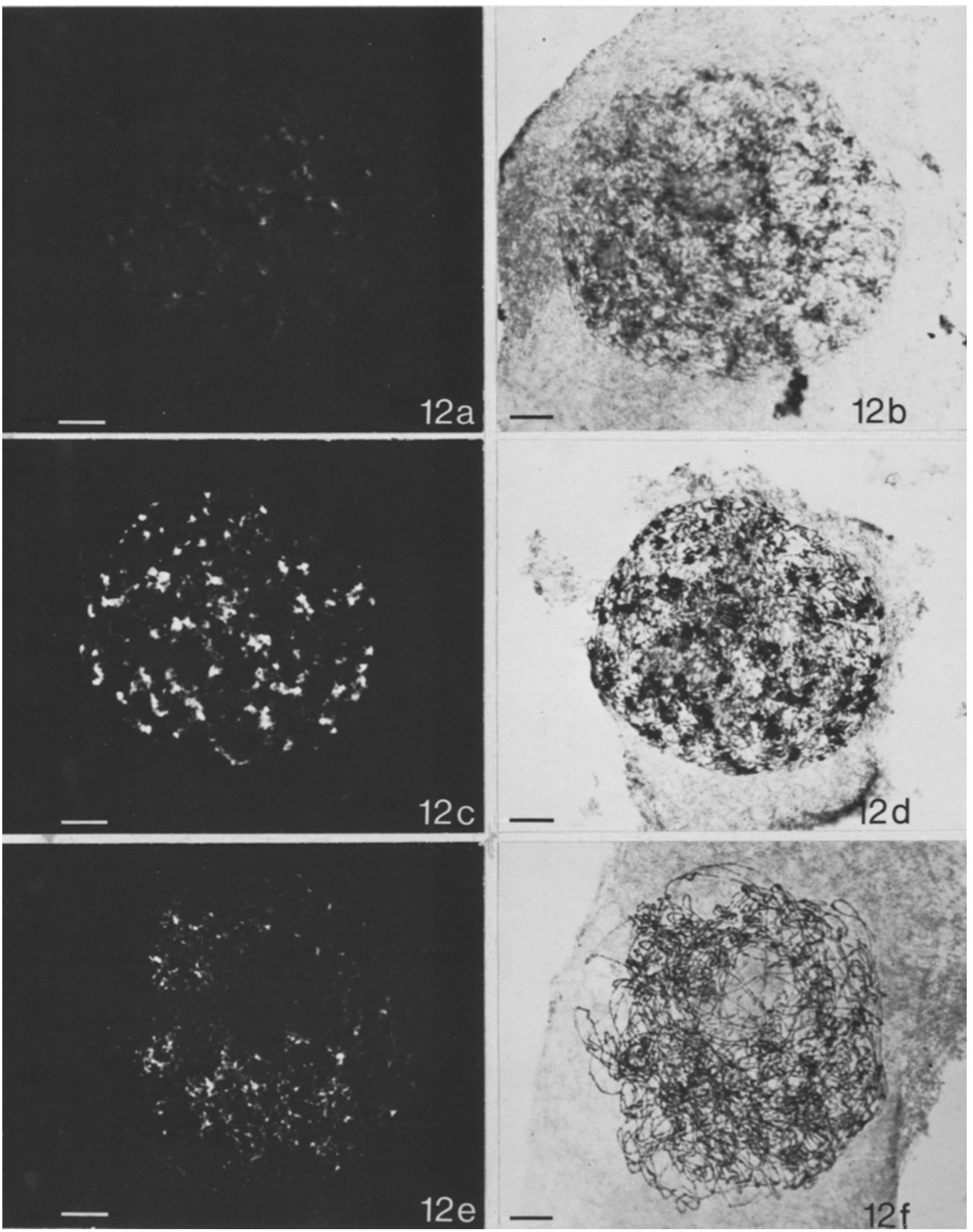


majority of the nuclei an identical amount of heterochromatin is observed after quinacrine mustard and orcein staining of the same nuclei (Figures $13 \mathrm{a}, \mathrm{c}$ ). This is easily judged if the micrographs of the orcein stained nuclei are printed with reverse contrast. In some nuclei however, the amount of heterochromatin stained with orcein is considerably larger (Figures 13b, d).

In root tips the interphase nuclei can be staged clearly by staining with quinacrine mustard (Figure 14). In the $G_{1}-S_{1}$ stage the chromocenters are characterized by an even fluorescence. In $\mathrm{S}_{3}$ a few strongly and some weakly fluorescing chromocenters are found, the latter probably corresponding to decondensed centers in the state of replication. The few strongly fluorescing chromocenters may represent already replicated and recondensed heterochromatin. The $\mathrm{G}_{2}$ nuclei are characterized by intensely fluorescing, partly bipartite chromocenters.

\section{DISCUSSION}

\subsection{Labelling procedure}

The series of relative short presynaptic stages in Lilium longiflorum require a pulse-labelling procedure in order to obtain a resolution of the different stages in the premeiotic DNA replication. It was accordingly considered desirable to use a shorter labelling method than that of TAYLOR and MCMASTER (71), in which whole buds are incubated for 24 hours. Pulse-labelling of whole anthers and extruded meiocytes is not feasible. HotTA and STERN (30) reported that there is a poor penetration of nutrients and tracers through the anther filament in excised anthers, and extruded meiocytes cannot be
Table IX

Area of heterochromatin in a population of nuclei in $\mathbf{S}_{2}$ after staining with quinacrine mustard and acetic orcein. Q.M., quinacrine mustard

$X$, mean area SD, standard deviation

\begin{tabular}{|c|c|c|c|}
\hline \multirow{2}{*}{$\begin{array}{c}\text { Nucleus } \\
\text { No. }\end{array}$} & \multicolumn{2}{|c|}{ Heterochromatin area $\mu \mathrm{m}^{2}$} & \multirow{2}{*}{$\begin{array}{c}\text { Q.M. area } / \\
\text { orcein area } \\
\%\end{array}$} \\
\hline & Q.M. & orcein & \\
\hline 1 & 122.8 & 179.3 & 68 \\
\hline 2 & 272.5 & 272.5 & 100 \\
\hline 3 & 238.0 & 238.0 & 100 \\
\hline 4 & 210.3 & 220.3 & 95 \\
\hline 5 & 123.8 & 131.8 & 93 \\
\hline 6 & 217.5 & 217.5 & 100 \\
\hline 7 & 151.0 & 167.1 & 90 \\
\hline 8 & 105.5 & 106.8 & 99 \\
\hline 9 & 184.8 & 191.8 & 94 \\
\hline 10 & 150.5 & 161.5 & 93 \\
\hline 11 & 166.5 & 166.5 & 100 \\
\hline 12 & 53.8 & 125.8 & 43 \\
\hline 13 & 107.0 & 177.8 & 61 \\
\hline 14 & 73.3 & 79.1 & 93 \\
\hline 15 & 87.8 & 102.8 & 85 \\
\hline 16 & 96.5 & 96.5 & 100 \\
\hline 17 & 101.5 & N.D. & \\
\hline 18 & 78.5 & N.D. & \\
\hline 19 & 176.5 & N.D. & \\
\hline \multirow[t]{3}{*}{20} & 215.3 & N.D. & \\
\hline & $\bar{X}: 146.7$ & $\bar{X}: 164.7$ & $\bar{X}: 89 \%$ \\
\hline & SD : 59.9 & $\mathrm{SD}: 53.5$ & \\
\hline
\end{tabular}

cultured appropriately during this interval since they revert to a mitotic division or undergo an achiasmatic meiosis $(54,63)$.

In the present procedure anther halves are floated on nutrient solution, and the meiocytes are still protected within the anther. No indications for preferential uptake of tracers in particular parts of the anther have been observed, and no aberrations have been observed to take place.

Metabolization of thymidine and thymine into other molecules than DNA could not be

Figure 12. Morphology of meiotic nuclei in $S_{3}(a, b)$, early leptotene (c,d) and mid leptotene $(e, f)$ after staining with quinacrine mustard (left, a,c,e) and after staining of the same nuclei with orcein (right, b,d,f). During the $S_{3}$ stage the heterochromatin is largely dispersed. At early leptotene it is prominently visible with both techniques. At mid-leptotene the heterochromatin is again decondensed. Identical patterns of heterochromatin are obtained with the two techniques. $\times 750(\mathrm{Bar}=10 \mu \mathrm{m})$. 

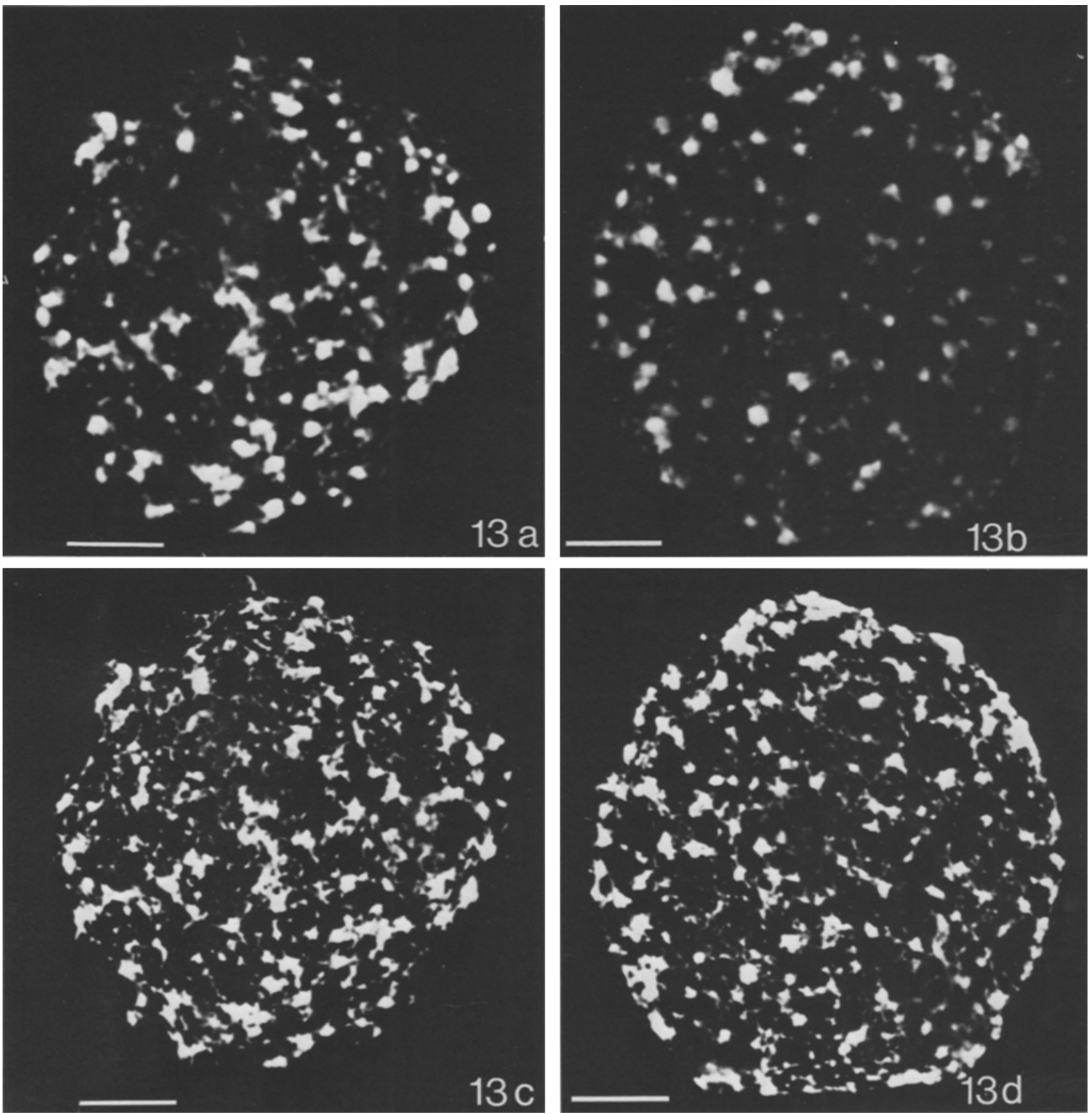

Figure 13. Pairs of light micrographs of two squashed nuclei in the premeiotic $\mathrm{S}_{2}$ stage, stained with quinacrine mustard $(a, b)$ and subsequently with orcein $(c, d)$. The micrographs of the orcein stained nuclei were printed with reversed contrast to facilitate the comparisons.

Identity of the chromocenters made visible with orcein and quinacrine mustard is evident in the nucleus of Figures $13 \mathrm{a}$ and $\mathrm{c}$. Only few of the chromocenters visible in the nucleus of Figure $13 \mathrm{~d}$ fluoresce.

$\times 1500(\mathrm{Bar}=10 \mu \mathrm{m})$ 

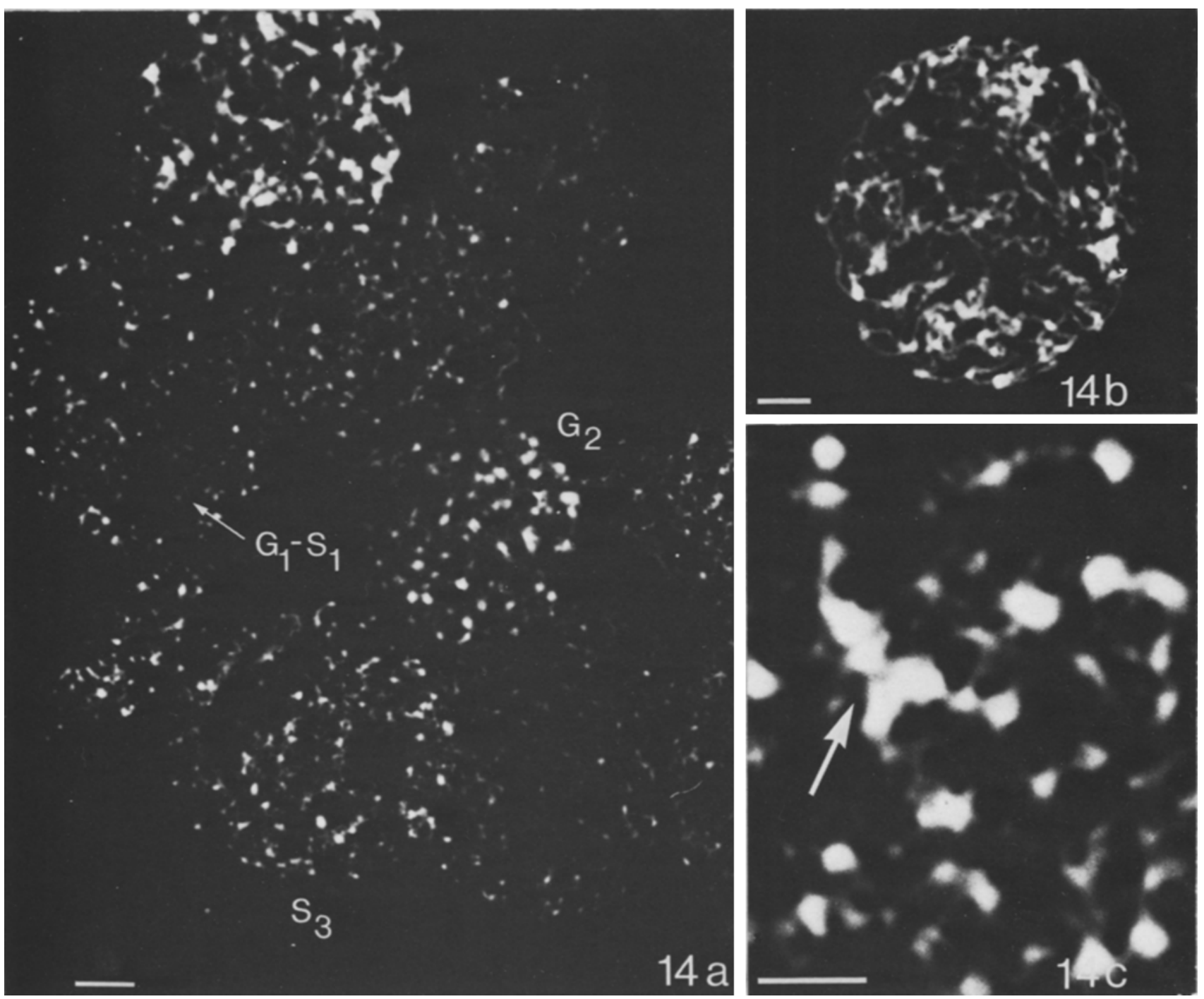

Figure 14. Fluorescence patterns in squashed root tip nuclei after staining with quinacrine mustard.

14a. Interphase nuclei in the $G_{1}-S_{1}$ stage can be identified by small evenly fluorescing chromocenters. The $S_{3}$ phase is characterized by a few strongly and some weakly fluorescing chromocenters. In $G_{2}$ big partly bipartite chromocenters fluoresce intensely.

$\times 750(\mathrm{Bar}=5 \mu \mathrm{m})$

14b. Nucleus in mitotic prophase. $\times 750(\mathrm{Bar}=5 \mu \mathrm{m})$

$14 \mathrm{c}$. Detail of $\mathrm{a}_{2}$ nucleus, composite chromocenters can be observed, arrows. $\times 3000(\mathrm{Bar}=5 \mu \mathrm{m})$.

adequately reduced. This situation which severely limits the usefulness of autoradiography has been reported repeatedly and seems to be a universal feature for anthers and buds $(37,38,44,70)$.

\subsection{The premeiotic DNA replication}

The present investigation has confirmed that DNA replication is terminated at the beginning of the early leptotene stage. In ultrastructural investigations I have found very few and ill 
defined lateral components at early leptotene in agreement with earlier results (65). The lateral components are accordingly first formed after the replication of the vast majority of the DNA is completed. This is in agreement with results obtained in the ascomycete Neottiella in which DNA replication takes place prior to nuclear fusion $(58,76)$ and with the autoradiographical and photometrical studies on the premeiotic DNA replication in Lilium by TAYLOR and MCMASTER (71), who have demonstrated a termination of DNA replication before leptotene. Biochemical studies have revealed that only $0.3 \%$ of the DNA remains unreplicated during leptotene $(29,32)$ and that this DNA is replicated during zygotene. Studies of other organisms have likewise shown a termination of DNA replication prior to leptotene $(17,39,46)$ or even before zygotene $(13,18)$.

\subsection{The phases of the premeiotic and somatic DNA replication}

Three major characteristics of the premeiotic $S$ phase have been observed in the present study: 1. All DNA in chromocenters is late replicating. 2. DNA replication in chromocenters is correlated with reversible decompaction of the heterochromatin. 3. Premeiotic DNA synthesis in euchromatin and heterochromatin is separated by a gap. The first two characteristics are shared with the somatic $S$ phase.

A delayed DNA replication in constitutive and facultative heterochromatin has been found to be a general rule in somatic cells (45), and available information on the premeiotic DNA synthesis likewise suggests a similar nonrandom replication $(13,21,39,43)$. Asynchronous replication of the DNA in centromeric heterochromatin of homologous chromosomes has been reported in the mouse (39) and early replication of DNA in some heterochromatic segments was found in the grasshoppers Myrmeleotettix and Corthippus (21).

The molecular mechanisms behind this differential timing of DNA synthesis in different chromatin portions are unknown. Analysis of the delayed replication of facultative heterochromatin $(43,51)$, suggests that compaction of chromatin imposes a physical constraint on the initiation of DNA replication. This hypothesis has obtained further support by the autoradiographical observation that DNA synthesis takes place only in diffuse chromatin $(41,61)$, and that chromocenters are decondensed while replicating $(1,42,48$, and this study). The dispersion of chromocenters during $S$ phase has been questioned $(16,53$, and NAGL (53) reported that the dispersion stage (Zerstäubungstadium), as described by HEITZ (23), marked instead the entry of the nucleus into the mitotic prophase. The results of the present investigation can resolve this conflict. Orcein and quinacrine mustard staining reveal a brief, reversible dispersion of chromocenters during the last part of premeiotic and somatic $S$ phase in Lilium longiflorum. After recondensation at early leptotene and at somatic $G_{2}$ the volume of the chromocenters has doubled, most likely due to their replicated state. The chromocenters loose their compactness and distinct staining behaviour as they are incorporated into the condensing leptotene chromosome and somatic prophase chromosome respectively. The decondensation of heterochromatin reported to take place during the premeiotic interphase in Plantago (36) and Oenothera (49) and a subsequent condensation of the dispersed heterochromatin before the entry of the nucleus into leptotene may be analogous to the situation found in lily.

A major gap in the middle of the premeiotic DNA replication as found in the present investigation has not been reported from other organisms. Waves of DNA synthesis have been reported for somatic cells, however $(67,68)$, and evidence for a minor delay in DNA replication in the middle of the somatic $S$ phase of root tip nuclei has been presented for Vicia (35) and Zea (15). It is conceivable that the temporary arrest in the midle of premeiotic DNA replication relates to the very protracted $S$ phase.

\subsection{Duration of the premeiotic $S$ phase}

The premeiotic $S$ phase in Lilium longiflorum has in the present study been found to last approximately 50 hours, while the duration of 
the somatic $S$ phase in root tips is on the average 8 hours. This increase by a factor 6 is in good agreement with the results from Triturus where the premeiotic and somatic $S$ phases lasted $9-10$ and 2 days respectively $(11,13)$. In Triticum and in the mouse the premeiotic DNA replication has been estimated to take twice as long as the somatic replication $(3,17)$.

The significance of this extension is at present not clear. Somatic $\mathrm{S}$ phase duration is generally estimated from rapidly dividing cell populations and large scale variations have been observed to take place during ontogenesis $(7,11.12,13,19)$. Likewise the different cell types in the root tip have been reported to have different $S$ phase durations (15) and a gradual increase in $\mathrm{S}$ phase length has been described for the last spermatogonial cell cycles in the mouse (50).

Variation in $\mathrm{S}$ phase duration is caused primarily by a variation in the number of replicons activated and less by variations in the speed of replication fork movement $(7,11,12$, 19). The rate of replication fork movement may vary two- to threefold during S phase (34) but the average rate of fork movement for the entire $S$ phase is identical for different tissues with varying durations of the DNA replication $(7,11,12,19)$. In agreement with this CALLAN obtained evidence for exceptionally long replicons and a normal rate of replication within the replicon in the premeiotic $S$ phase of Triturus $(11,12)$.

The mechanism that determines how many replicons are activated is unknown. Blumenthal et al. (7) suggested that comparatively fewer replicons were activated in the DNA of heterochromatin. This would extend the duration of the $\mathbf{S}$ phase in nuclei with large amounts of heterochromatin. This hypothesis has been questioned, however $(19,28,78)$. Assuming a constant rate of replication for the replicon, the present results likewise suggest that the number of replicons is the same for the $S_{1}$ and $S_{3}$ period of the premeiotic $S$ phase. The two phases are of equal duration with all of the heterochromatin being replicated in $\mathrm{S}_{3}$. Similar results have been obtained by LIMA-DE-FARIA and JAWORSKA (47), who noted a good correlation between relative DNA content and dura- tion of replication of eu- and heterochromatin segments of Secale chromosomes. CaLlan (12) suggested that during the premeiotic DNA replication the chromomere could correspond to a replicon, and presented evidence for this from Triturus. If similar calculations are carried out on Lilium longiflorum assuming a rate of replication fork movement of $30 \mu \mathrm{m} / \mathrm{hour}$ (72), the minimum number of replicons required to replicate the $60 \mathrm{~m}$ of DNA (33) in Lilium would be 2500. (Duration of $S_{1}$ and $S_{3}: 40$ hours, bidirectional replication rate of a replicon: $60 \mu \mathrm{m} /$ hour.) BELLING (2) found 2000 chromomeres at pachytene in Lilium pardalinum and the number of chromomeres in Lilium longiflorum is probably within the same order of magnitude. A minimum of 12 replicons would thus be required to replicate the DNA of one chromomere. Evidence linking the state of chromatin as define by light microscopy with the number of replicons activated is accordingly conflicting.

\subsection{The heterochromatin of Lilium Iongiflorum}

According to the present investigation $50-60 \%$ of the premeiotic synthesis may be assigned to heterochromatin. This value agrees with the results of OONO and HOTTA (55) who found that two thirds of the DNA in the premeiotic nuclei was located in condensed chromatin. Moreover it can be stated from the volume determinations (sections 3.5, 3.7, Figures 7,9 ) that this chromatin fraction occurs in variable amounts in the synchronous premeiotic nuclei, the mean value being $2-3$ times higher than in somatic nuclei.

Limited information is at present available on the fraction of the genome which participates in the formation of the chromocenters of premeiotic and somatic nuclei. The $\mathrm{C}$ banding experiments suggest that the $\mathrm{C}$ bands fit the definitions for constitutive heterochromatin ( 9 , $22)$, since they remain condensed during interphase. This fraction however only accounts for $5 \%$ of the genome (26). The results from the quinacrine mustard and orcein staining experiments are less clear cut since the intensity of fluorescence to some extent depends on the morphological preservation of the chromatin (26). If taken at face value the results 
in Table IX indicate that both the $\mathrm{Q}$ bands and some interband regions may remain condensed during premeiotic interphase. The majority of the premeiotic heterochromatin can therefore not be classified as constitutive heterochromatin.

\subsection{DNA replication, heterochromatin and} meiosis

More information is required before detailed suggestions can be made as to the premeiotic control of the later events in meiosis. It is conceivable that the observed characteristics of the premeiotic $S$ phase, i.e. extended duration, late replication of a quantitative variable fraction of the chromatin and the temporary arrest of DNA replication during the $S_{2}$ interval have influenced on the organization of the chromosomes, chromosome pairing and crossing-over.

It can be proposed that the longer replicons of the premeiotic $\mathrm{S}$ phase are a necessary prerequisite for the organization of the leptotene chromosome at a level below the chromomere. This process might also be influenced by the unique meiotic histone composition (60) and the possible uncoupling of DNA and histone synthesis $(8,66)$.

The $0.3 \%$ of the DNA which remains unreplicated until zygotene $(29,32)$ and is of possible significance for chromosome pairing in Lilium longiflorum may relate to the arrest in the DNA replication at the $S_{2}$ interval. Likewise it can be visualized that the extended $S$ phase would facilitate alterations in the organization of the chromatin housing early and late replicated DNA respectively, thereby making some of these regions inaccessible to entrapment within the synaptinemal complex. This proposal would be in line with the preselection hypothesis presented by STERN, WESTERGAARD and VON WETTSTEIN (65).

\section{ACKNOWLEDGEMENTS}

I am indebted to the late Professor Mogens WESTERGAARD for suggesting this project and for his helpful guidance. I wold also like to thank Professor Herbert STERn and Professor DITER VON WETTSTEIN for valuable discussions and comments on the manuscript. The staff of the phytotron at the Royal College of Forestry in Stockholm are thanked for their care of the plants. This work was supported in part by grant GM - 22051 of the National Institutes of Health, U.S. Public Health Service to Professor Diter von WETTSTEIN.

\section{REFERENCES}

1, BARLOW, P. W.: The relation of the dispersion phase of chromocentric nuclei in the mitotic cycle to DNA synthesis. Protoplasma 90, 381-382 (1976)

2. Belling, J.: The ultimate chromomeres of Lilium and Aloe with regard to the number of genes. Univ. Calif. Pub. Bot. 14, 307-318 (1928)

3. Bennett, M. D. \& J. B. Smith: The effect of polyploidy on meiotic duration and pollen development in cereal anthers. Proc. R. Soc. Lond. B. 181, 81-107 (1972)

4. Bennett, M. D., V. C. Chapman \& R. Riley: The duration of meiosis in pollen mother cells of wheat, rye and Triticale. Proc. R. Soc. Lond. B. 178, 259-275 (1973)

5. Bennett, M. D. \& H. Stern: The time and duration of female meiosis in Lilium. Proc. R. Soc. Lond. B. 188, 459-475 (1975)

6. BennetT, M. D. \& H. Stern: The time and duration of preleptotene chromosome condensation stage in Lilium hybrid cv. Black Beauty. Proc. R. Soc. Lond. B. 188, 477-493 (1975)

7. Blumenthal, A. B., H. J. Kriegstein \& D. S. HoGNESS: The units of DNA replication in Drosophila melanogaster chromosomes. In: Cold Spring Harbor Symp. Quant Biol. 38, 205-223 (1973)

8. Bogdanov, Yu. F., A. A. Strokov \& S. A. RESNIKOVA: Histone synthesis during meiotic prophase in Lilium. Chromosoma (Berl.), 43, 237 396 (1974)

9. Brown, S. W.: Heterochromatin. Science 151, $417-425$ (1966)

10. Burns, J. A.: Preleptotene chromosome contraction in Nicotiana species. J. Hered. 63, 175-178 (1972)

11. Callan, H. G.: Replication of the DNA in the 
chromosomes of eukaryotes. Proc. Roy. Soc. Lond. B. 181, 19-41 (1972)

12. CAllaN, H. G.: DNA replication in chromosomes of eukaryotes. In: Cold Spring Harbor Symp. Quant. Biol. 38, 195-204 (1973)

13. Callan, H. G. \& J, H. Taylor: A radioautographic study of the time course of male meiosis in the newt Triturus vulgaris. J. Cell Sci. 3, 615-625 (1968)

14. Caspersson, T., L. Zech, E. J. Modest, G. E. Foley, U. WAGH \& E. Simonson: Chemical differentiation with fluorescent alkylating agents in Vicia faba metaphase chromosomes. Exp. Cell Res. 58, 128-140(1969)

15. Clowes, F,A. L.: The duration of the $G_{1}$ phase of the mitotic cycle and its relation to radiosensitivity. New Pythol. 64, 355-359 (1965)

16. Comings, D. E.: The duration of replication of the inactive $\mathrm{X}$ chromosome in humans based on the persistance of the heterochromatic sex chromatin body during DNA synthesis. Cytogenetics 6, 20-37 (1967)

17. Crone, M., E. Levy \& H. Peters: The duration of premeiotic DNA synthesis in mouse. Exp. Cell Res. 39, 678-688 (1965)

18. DE, D. N.: Autoradiographic studies of nucleoprotein metabolism during the division cycle. The Nucleus 4, 1.24 (1961)

19. Edenberg, H. J. \& J. A. Huberman: Eukaryotic chromosome replication. Ann. Rev. Genet. 9, 245-284 (1975)

20. ERICKSON, R. O.: Cytological and growth correlation in the flower bud and anther development of Lilium longiflorum. Amer. J. Bot. 35, 729-739 (1948)

21. Fox, D. P., G. M. Hewitt \& D. L. Hall: DNA replication and RNA transcription of euchromatic and heterochromatic chromosome regions during grasshopper meiosis. Chromosoma (Berl.) 45, 43-62 (1974)

22. Heitz, E.: Das Heterochromatin der Moose. Jahrb. f. wiss. Bot. 69, 762-818 (1928)

23. HeITZ, E.: Heterochromatin, Chromocentren, Chromomeren. Ber. dtsch. bot. Ges. 47, 276-284 (1929)

24. HeNDERSON, S. A.: The time and place of meiotic crossing over. Ann. Rev. Genet. 4, 295-324 (1970)

25. Hiraoka, T.: Studies of mitosis and meiosis in comparison. III. Behaviour of chromonemata in the pre-leptotene state in meiosis. Cytologia (Tokyo) 11, 473-482 (1941)

26. Holm, P. B.: The $C$ and $Q$ banding patterns of the chromosomes of Lilium longiflorum (Thunb.). Carlsberg Res. Commun. 41, 217-224 (1976)

27. Holm, P. B.: Three-dimensional reconstruction of chromosome pairing during the zygotene stage of meiosis in Lilium longiflorum (Thunb.). Car'sberg Res. Commun. 42, 103-151 (1977)

28. HorI, T. A. \& K. G. LARK: Autoradiographic studies of the replication of satellite DNA in the kangaroo rat. Autoradiographs of satellite DNA. J. Mol. Biol. 88, 221-232 (1974)

29. Hotta, Y., M. Ito \& H. Stern: Synthesis of DNA during meiosis. Proc. Nat. Acad. Sci. 56, 11841191 (1966)

30. HotTA, Y. \& H. Stern: Transient phosphorylation of deoxyribosides and regulation of deoxyribonucleic acid synthesis. J. Biophys. Biochem. Cytol. 11,311-319(1961)

31. HOTTA, Y. \& H. STERN: Inhibition of protein synthesis during meiosis and its bearing on intracellular regulation. J. Cell Biol. 16, 259-279 (1963)

32. HotTA, Y. \& H. SteRn: Analysis of DNA synthesis during meiotic prophase in Lilium. J. Mol. Biol. 55, 337-355 (1971)

33. HOTTA, Y.\& H. Stern: Zygotene and pachytenelabelled sequences in the meiotic organization of chromosomes. In: "The Eucaryotic Chromosome", W. S. Peacock \& R. D. Brock, eds., Austral. Nat. Univ. Press, Canberra pp. 283$305(1975)$

34. Housman, D. \& J. A. Huberman: Changes in the rate of DNA replication fork movement during $S$ phase in mammalian cells. J. Mol. Biol. 94, 173181 (1975)

35. Howard, A. \& D. L. Dewey: Non-uniformity of labelling rate during DNA synthesis. Exp. Cell Res. 24, 623-624 (1961)

36. Hyde, B. B.: Differentiated chromosomes in Plantago ovata. A mer. J. Bot. 40, 809-815 (1953)

37. ITо, M. \& Y. HotTA: Radioautography of incorporated ${ }^{3} \mathrm{H}$-thymidine and its metabolism during meiotic prophase in microsporocytes of Lilium. Chromosoma (Berl.) 43, 391 -398 (1973)

38. ITo, M. \& H. Stern: Studies of meiosis in vitro I. In vitro culture of meiotic cells. Devel. Biol. 6, 36-53(1967)

39. Kofman Alfaro, S. \& A. C. Chandley: Meiosis in the male mouse. An autoradiographic investigation. Chromosoma (Berl.) 31, 404-420 (1970)

40. Kongsuwan, K. \& D. R. Smyth: Q-bands in Lilium and their relationship to $\mathrm{C}$-banded heterochromatin. Chromosoma (Berl.) 60, 169178 (1977)

41. KURolwa, T.: Fine structure of interphase nuclei III. Replication site analysis of DNA during the S period of Crepis capillaris. Exp. Cell Res. 83, 387 . 398 (1974) 
42. Lafontaine, J. G. \& A. LoRD: An ultrastructural and autoradiographic study of the evolution of the interphase nucleus in plant meristematic cells (Allium porrum). J. Cell Sci. 14, 263-287 (1974)

43. Lima-DE-Faria, A.: Differential uptake of tritiated thymidine into hetero- and euchromatin in Melanoplus and Secale. J. Biophys. Biochem. Cytol. 6, 457-466 (1959)

44. Lima-DE-FARIA, A: Labelling of the cytoplasm and the meiotic chromosomes of Agapanthus with ${ }^{3} \mathrm{H}$-thymidine. Hereditas 53, 1-18 (1965)

45. LIMA-DE-FARIA, A.: DNA replication and gene amplification in heterochromatin. In: "Handbook of Molecular Cytology", Lima-de-Faria, A., ed., North Holland Publishing Co., Amsterdam and London, pp. 277-325 (1969)

46. Lima-de-Faria, A. \& K. Borum: The period of DNA synthesis prior to meiosis in the mouse. J. Cell Biol. 14, 381-389 (1962)

47. Lima-DE-FARIA, A. \& H. Jaworska: The relation between the chromosome size gradient and the sequence of DNA replication in rye. Hereditas $70,39-58$ (1972)

48. LORD, A. \& J. G. LAFONTAINE: An ultrastructural and radioautographic study of the evolution of the interphase nucleus in plant meristematic cells (Raphanus sativus). J. Cell Sci. 21, 193-207(1976)

49. MarquardT, H.: Die Meiosis von Oenothera 1. Z. Zellforsch. 27, 190-210 (1937)

50. MONESI, V.: Autoradiographic study of DNA synthesis and the cell cycle in spermatogonia and spermatocytes of mouse testis using tritiated thymidine. J. Cell Biol. 14, 1-18 (1962)

51. Morishima, A., M. M. Grumbach \& J. H. TAYLOR: Asynchronous duplication of human chromosomes and the origin of sex chromatin. Proc. Nat. Acad. Sci. 48, 756-763 (1962)

52. Moses, M. J. \& J. H. TAYloR: Desoxypentose nucleic acid during microsporogenesis in Tradescantia. Exp. Cell Res. 9, 474-488 (1955)

53. NAGL, W.: The mitotic and endomitotic nuclear cycle in Allium carinatum II. Relations between DNA replication and chromatin structure. Caryologia 23, 71-78 (1970)

54. NinnemanN, H. \& B. Epel: Inhibition of cell division by blue light. Exp. Cell Res. 79, 318-326 (1973)

55. OONo, K. \& Y. HotTA: The relation of chromosome compaction to DNA synthesis during meiosis in Lilium. Cell Structure and Function 4, $1-9(1976)$

56. Quastler, H.\& F. G. Sherman: Cell population kinetics in the intestinal epithelium of the mouse. Exp. Cell Res. 17, 420-438 (1959)

57. Rasmussen, S. W.: The meiotic prophase in
Bombyx mori females analyzed by three dimensional reconstructions of synaptonemal complexes. Chromosoma (Berl.) 54, 245-293 (1976)

58. Rossen, J. M. \& M. Westergaard: Studies on the mechanism of crossing over II. Meiosis and the time of meiotic chromosome replication in the ascomycete Neottiella rutilans (Fr.) Dennis. Compt. Rend. Trav. Lab. Carlsberg 35/9, 233-260 (1966)

59. Roth, I. F. \& M. ITO: DNA dependent formation of the synaptinemal complex. J. Cell Biol. 35, 247-255 (1967)

60. Sheridan, W. F. \& H. Stern: Histones of meiosis. Exp. Cell Res. 45, 325-335 (1967)

61. SPerling, K. \& P. N. RAO: Mammalian cell fusion V. Replication behaviour of heterochromatin as observed by premature chromosome condensation. Chromosoma (Berl.) 45, 121-131 (1974)

62. Spurr, A. R.: A low-viscosity epoxy resin embedding medium for electron microscopy. J. Ultrastruc. Res. 26, 31-43 (1969)

63. Stern, H. \& Y. HotTA: DNA synthesis in relation to chromosome pairing and chiasma formation. Genetics 61, Suppl. 1,27-39(1969)

64. STERN, H. \& Y. HOtTA: Biochemical controls of meiosis. Ann. Rev. Genet. 7, 37-66 (1973)

65. Stern, H., M. WestergaArd \& D. von WetTSTEIN: Presynaptic events in meiocytes of Lilium longiflorum and their relation to crossingover: A preselection hypothesis. Proc. Nat. Acad. Sci. 72, 961-965 (1975)

66. Strokov, A. A. Yu, F. Bogdanov \& S. A. RESNikova: A quantitative study of histone of meiocytes II. Polyacrylamide gel electrophoresis of isolated histones from Lilium microsporocytes. Chromosoma (Berl.) 43, 247-260 (1973)

67. Stubblefield, E.: The kinetics of DNA replication in chromosomes. In: "The Cell Nucleus II.", Busch, H., ed., Academic Press, New York and London, pp. 149-162(1974)

68. Stubblefield, E. \& M. Gay: Quantitative tritium autoradiography of mammalian chromosomes II. The kinetics of DNA synthesis in individual chromosomes of chinese hamster fibroblasts. Chromosoma (Berl.) 31, 79-90 (1970)

69. Sumner, A. T.: A simple technique for demonstrating centromeric heterochromatin. Exp. Cell Res. 75, 304-306 (1972)

70. Takats, S. T. \& R. M. S. Smellie: Thymidine degradation products in plant tissue labelled with tritiated thymidine. J. Cell Biol. 17, 59-66 (1965)

71. TAYLOR, J. H. \& R. MCMASTER: Autoradiograp- 
hic and microphotometric studies of desoxyribose nucleic acid during microgametogenesis in Lilium longiflorum. Chromosoma (Berl.) 6, 489-521 (1954)

72. VAN'T HoF, J.: Replicon size and rate of fork movement in early $\mathbf{S}$ of higher plant cells (Pisum sativum). Exp.Cell Res. 103, 395-403 (1976)

73. Vosa, C. G. \& R. MARchI: Quinacrine fluorescence and Giemsa staining in plants. Nature New Biol. 237, 191-192 (1972)

74. WALTERS, M. S.: Evidence on the time of chromosome pairing from the preleptotene spiral stage in Lilium longiflorum "Croft". Chromosoma (Berl.) 29, 375-418 (1970)

75. WALTERS, M. S.: The relation of temperature to preleptotene chromosome contraction in Lilium. Chromosoma (Berl.) 61, 23-39 (1977)

76. Westergaard, M. \& D. von WetTstein: Studies on the mechanism of crossing-over IV. The molecular organization of the synaptinemal complex in Neottiella (Cooke) Saccardo (Ascomycetes). Compt. Rend. Trav. Lab. Carlsberg 37, 239 . 268 (1970)

77. WestergaArd, M. \& D, von WetTStein: The synaptinemal complex. Ann. Rev. Genet. 6, 71$110(1972)$

78. ZAKIAN, V. A.: Electron microscopic analysis of DNA replication in main band and satellite DNAs of Drosophila virilis. J. Mol. Biol. 108, 305-331 (1976) 